\title{
The spillover effects of MD\&A disclosures for real investment: The role of industry competition ${ }^{\star, \star \star}$
}

\author{
Art Durnev $^{\mathrm{a}}$, Claudine Mangen ${ }^{\mathrm{b}, *}$ \\ ${ }^{a}$ Henry B. Tippie College of Business, University of Iowa, 21 E Market St, Iowa City, IA 52242, USA. \\ ${ }^{b}$ John Molson School of Business, Concordia University, 1455, de Maisonneuve W, Montreal, QC H3G \\ $1 M 8, C A N A D A$.
}

\begin{abstract}
We explore whether disclosures in the Management Discussion \& Analysis (MD\&A) have spillover effects for investment and investment efficiency, and whether spillover effects vary with competition. We focus on the tone of MD\&A disclosures and document that the association between a company's investments and the tone of its rivals' MD\&A disclosures is positive. Moreover, this association is moderated by competition; it is stronger when firms operate in industries that have lower entry costs, are larger, and have less substitutable products. We obtain similar results for investment efficiency. Overall, our evidence suggests that MD\&A disclosures have spillover effects for investment that can improve investment efficiency, and that spillover effects are moderated by industry competition.

Keywords: spillover effects, disclosures, competition, investment, investment efficiency

JEL: D43, G31, M4, M41
\end{abstract}

${ }^{\star}$ We are grateful for the helpful comments and suggestions from Ana Albuquerque, Rui Albuquerque, John Core, Liz Demers, Rucsandra Moldovan, Amrita Nain, two anonymous referees and seminar participants at the Conference on Discourse Approaches to Financial Communication, the International Conference of the French Finance Association, the European Accounting Association Meeting, the Canadian Academic Accounting Association Meeting, the CGA/University of Manitoba Accounting Research Conference, ESSEC Paris, Catolica Lisbon, the University of Alberta, and the Université de Toulouse. All errors are our own.

${ }^{\star}$ Funding: Claudine Mangen received financial support from the RBC Professorship in Responsible Organizations and from the Social Sciences and Humanities Research Council of Canada [grant number: 8642007-0223].

${ }^{*}$ Corresponding author

Email addresses: artem-durnev@uiowa.edu (Art Durnev), claudine.mangen@concordia.ca (Claudine Mangen) 


\section{Introduction}

Research on the spillover effects for investment examines how a company's investment (e.g., property, plant and equipment; research and development) is shaped by other firms. This research has analyzed spillover effects of different activities, including securities litigation, hedge fund activism and investments (Arena and Julio, 2015; Dougal et al., 2015; Aslan and Kumar, 2016). Of particular interest to accounting researchers are the spillover effects of disclosures (Roychowdhury et al., 2019). While studies have explored the spillover effects of disclosures for investment and have shed light on their causes and effects (Sadka, 2006; Durnev and Mangen, 2009; Badertscher et al., 2013; Beatty et al., 2013; Shroff et al., 2017), this work leaves two salient questions unaddressed.1

The first question centers on whether textual disclosures have spillover effects for investment. The evolution of information processing, transfer, and storage technologies during the last 25 years has changed how firms communicate. Perhaps among the most visible changes is the increasing volume of textual disclosures that firms make available through filings with securities regulators, on their websites, in press releases, on social media, etc. Textual disclosures are nuanced in their content and format, allowing firms to provide subtle information on complex issues; yet, they are also malleable. We consider textual disclosures by focusing on the Management Discussion \& Analysis (MD\&A) and exploring the spillover effects of MD\&As for investment.

The second question considers whether spillover effects vary with competition. Firms operate in settings that often cannot be characterized by perfect competition and that, instead, are better thought of as oligopolistic. In an oligopolistic setting, a firm considers the effects on its rivals of its disclosure and investment decisions. These effects are influenced by the extent to which the firm and its rivals compete and try to win customers from each other. We

\footnotetext{
${ }^{1}$ Spillover effects operate through three channels. The financing channel involves a firm's disclosures that affect information asymmetries between the firm and investors, and the cost at which other companies can externally fund their investments (Biddle et al. 2009; Shroff et al. 2017). The real channel refers to disclosures that shape investments of the disclosing firm, which influence the investment choices of other companies (Sadka, 2006). The learning channel, which is the perspective we adopt, is in effect when a firm's disclosures provide other companies with information about unknown investment opportunities (Durnev and Mangen, 2009, Badertscher et al. 2013, Beatty et al. 2013).
} 
consider competition by exploring three fundamental conditions under which firms compete: entry costs, industry size, and product substitutability (Raith, 2003, Karuna, 2007).

We start our analysis by exploring the spillover effects of MD\&As for investment. MD\&As are qualitative and consist of text rather than numbers. We capture the content of MD\&As using their tone, which allows us to abstract away from the many different terms and definitions that firms use for conveying similar ideas and, instead, to consider underlying meanings (Cole and Jones, 2005). We capture tone via the word list from Loughran and McDonald (2011), which has been widely used in the literature (Loughran and McDonald, 2016). Our sample period ranges from 1996 to 2016.

We find that a company's investments are significantly positively associated with the tone of its rivals' MD\&As. We measure this association using a regression of changes in a company's investments between two subsequent years on changes in the tone of its rivals' MD\&As, and we control for other investment determinants. We measure investment using the sum of capital expenditures, $R \& D$ expenditures, and acquisitions minus cash receipts from the sale of property, plant, and equipment. We define a company's rivals as firms that operate in its primary 3-digit SIC code (excluding the company). From an economic perspective, our evidence shows that the change in the company's investments increases by 45.6 cents for every $\$ 100$ of assets when the change in the tone of its rivals' MD\&As rises by one standard deviation. In comparison, the change in the company's investments rises by $\$ 3.6$ for every $\$ 100$ of assets when the change in rivals' investments, a key determinant of the company's investment, increases by one standard deviation.

We then turn to the question of how competition shapes the spillover effects of MD\&As. We document that the association between a company's investments and the tone in its rivals' MD\&As varies with our three competition fundamentals: the association is stronger when the company and its rivals operate in industries that have lower entry costs, are larger, and have less substitutable products.

Next, we explore the implications of MD\&As for investment efficiency. Ex ante, it is not clear how the efficiency of a company's investments is affected by its rivals' MD\&As. 
On one hand, rivals' MD\&As can enhance the efficiency of the company's investments when they provide its managers with new information about the net present value of existing and planned investments (Durnev and Mangen, 2009). On the other hand, rivals' MD\&As can harm the efficiency of the company's investments when the company experiences governance problems - for instance when its managers are entrenched and use information in rivals' MD\&As to justify investing in weak divisions (Scharfstein and Stein, 2000). Our results suggest that the tone of rivals' MD\&As can enhance the efficiency of a company's investments. In particular, we find that a company's investments are more efficient when the tone of its rivals' MD\&As is more optimistic or more pessimistic. We interpret higher optimism and higher pessimism in MD\&A tone as proxying for MD\&A tone that carries more news. We also study whether MD\&A spillover effects for investment efficiency vary with competitive fundamentals. We find that the spillover effects of MD\&A tone for investment efficiency are generally stronger when investing companies and their disclosing rivals operate in industries that have lower entry costs and are larger.

Finally, we perform the following additional tests. First, we contrast MD\&A text that is specific to disclosing firms (e.g., information about firm-specific costs) with MD\&A text that is common to all firms in the industry (e.g., information about industry demand). Firmspecific and common MD\&A text may be used differently during the investment process. We find that the tone of both firm-specific and common MD\&A text has spillover effects for investment and investment efficiency. Second, our investment efficiency analysis implicates a two-stage regression approach that can bias our results (Chen et al., 2018). To address this concern, we use alternative approaches for exploring investment efficiency Ferreira and Laux (2007); Biddle et al. (2009); Francis and Martin (2010); Glaser et al. (2013), and our results hold. Third, we show that our competition results hold for disclosures other than MD\&As: we document that information released at restatement announcements has spillover effects for investment and investment efficiency that are moderated by competitive fundamentals. Fourth, our findings hold when we control for bias in MD\&As, when we focus on the tone of forward-looking statements in MD\&As ( $\mathrm{Li}, 2010 \mathrm{a})$, and when we use alternative word lists (i.e., the General Inquirer and Diction). Finally, we show that our results are robust to different scenarios: we use an alternative definition of rivals (Hoberg and Phillips, 2010, 
2016), we control for unmodeled investment opportunities (Erickson and Whited, 2000, 2002), and we examine components of investments.

Collectively, our results suggest that MD\&A disclosures have spillover effects for investment and investment efficiency, and that these spillover effects vary with competition. We contribute to the literature in three ways. First, we show that textual disclosures have spillover effects for investment, which can be beneficial for the investing company. To date, research on spillover effects has not explored the text of disclosures. Instead, it has focused on the publication of disclosures and on their numerical content. It has cautioned how these disclosures can be detrimental for investing companies. For instance, companies boost investment when rivals disclose fraudulent reports; later on, once the fraud is revealed, they revise their investment (Durnev and Mangen, 2009; Beatty et al., 2013). Second, we show how competition moderates the spillover effects of disclosures for investment and investment efficiency. By focussing on this moderating role of competition, our work complements prior research on competition (discussed in Section 2). This research has not considered the moderating role of competition and has instead examined the consequences of competition for disclosures and for investment (see, for example, Hoberg and Phillips, 2010, Li et al., 2013) $2^{2}$ Overall, our first two contributions focus on the accounting literature and address the call in Leuz and Wysocki (2016) for more research on the spillover effects of disclosures for real investment.

Finally, we contribute to the growing literature in economics and finance that examines the determinants of investment. According to Tobin (1969), a company's marginal $Q$ should be the sole determinant of investment. Yet, the literature shows that the relation between investment and marginal $Q$ (proxied for by average $Q$ ) is weak (Barro, 1990), and recent studies have examined factors responsible for this weak relation. For example, Gutiérrez and

\begin{tabular}{|l|}
\hline \hline${ }^{2}$ Hoberg and Phillips $(2010)$ find that firms that use similar language to describe products in their 10-Ks \\
\hline (suggesting more similarities between firms and higher product substitutability) are more likely to merge and, \\
\hline after the merger, are more profitable and introduce more new products. Li et al. $\mid(2013)$ document that com- \\
\hline panies that mention competition more often in their 10-Ks (and companies that operate in industries where \\
\hline rivals mention competition more often in their 10-Ks) have higher rates of diminishing returns on new invest- \\
ments and existing assets. Both studies imply that competition has repercussions for a company's investment \\
and its subsequent performance; in comparison, our study suggests that competition has implications for the \\
\hline association between a company's investments and its rivals' MD\&As. \\
\hline \\
\hline
\end{tabular}


Philippon (2017) argue that it is due to the rise in concentration; Feenstra and Weinstein (2017) attribute it to globalization; and Peters and Taylor (2017) explore the role of intangible capital in the investment- $Q$ relation. We advance this literature by providing a novel determinant of corporate investment: publicly available textual disclosures of rival firms.

The rest of this paper is organized as follows. Section 2 develops testable predictions. Section 3 presents the sample and defines the main variables. Section 4 details the findings for the spillover effects of MD\&As for investment, while Section 5 focuses on the spillover effects of MD\&As for investment efficiency. Section 6 discusses additional tests. Section 7 concludes.

\section{Empirical Predictions}

Managers select investment $I$ that maximizes the net present value of future cash flows, $N P V(I)=\frac{f(I)}{1+r}-I$, where $f(\cdot)$ is the investment function and $r$ is the risk-adjusted discount rate. Managers can lack complete information about $N P V(I)$; they may not know future demand nor prospective production costs. To mitigate incomplete information, managers look for information that adds to their knowledge about the NPV. A rival firm can be a source of information; firms in an industry have different information due to disparities in prior investments, information gathering activities, and in-house knowledge (Zhu and Weyant, $2003)$.

Financial reports represent a prominent information source, in particular MD\&As (Marin and Poulter, 2004), which are intended to explain a firm's financial statements (Hoberg, 2016). Since 1980, the Securities and Exchange Commission (SEC) has required, via Item 303 (a) of Regulation S-K, that MD\&As describe, in a forward-looking manner, qualitative and quantitative factors necessary for comprehending the firm, including key shifts in operations (e.g., revenue increases) and capital expenditures (e.g., ongoing and planned projects) $!^{3}$

\footnotetext{
${ }^{3}$ The SEC has required prospective disclosures since 1968, starting with the discussion of non-recurring components in earnings. In 1974, the SEC mandated that firms discuss trends in operations; in 1989, it released guidelines to clarify its expectations of MD\&As. In 2010, it followed up on general directives for MD\&As issued in 2003 with more specific guidance. Our empirical analysis controls for regulation changes, as detailed in Section 4 .
} 
Firms generally follow these requirements: MD\&As are altered after changes in operations, capital resources, and acquisitions and divestitures (Brown and Tucker, 2011), and they are informative about future earnings, cash flows, investments, and firm value, especially when firms undergo a business change (Bryan, 1997; Li, 2010a, Ball et al., 2015; Frankel et al., 2016). MD\&As do not merely rehash information found elsewhere but provide information that is incremental to earnings announcements (Davis and Tama-Sweet, 2012). Recent research cautions that annual reports, which include the MD\&A, have become longer, more boilerplate, and redundant over time (Dyer et al., 2016, 2017). However, this evolution is not driven by annual report disclosures about topics relevant for investment decisions (e.g., performance, business operations and strategy, business structure and M\&A, intellectual property and R\&D) but by disclosures related to compliance with reporting standards (Dyer et al., 2017).

While research has thus explored how a firm's MD\&As are associated with its own future prospects, it has yet to examine whether its MD\&As have spillover effects for the investments of other companies in its industry, whether spillover effects can be beneficial for these companies, and how spillover effects vary with competition. We address these questions in four steps.

First, we explore whether the tone of a firm's MD\&As can provide information useful for the investment decisions of other companies in its industry. We test whether a company's investments are associated with the tone of its rivals' MD\&As. We have no prior for the direction of this association, because the association depends on industry competition, as we explain below. Our first hypothesis, stated in the alternate form, is as follows.

H1. Ceteris paribus, a company's investments are associated with the tone of its rivals' MD\&As.

Next, we analyze how the association between a company's investments and the tone of its rivals' MD\&As is influenced by competition. Competition represents the extent to which a company and its rivals try to win customers from each other (Karuna, 2007). We define rivals at the industry level; an industry includes firms that sell substitutable products (Bresnahan 
and Reiss, 1987). $4^{4}$ In the long run, competition in an industry is endogenous and determined by entry and exit. We focus on three fundamental conditions under which firms compete: entry costs, industry size, and product substitutability (Raith, 2003; Karuna, 2007). Entry costs refer to the costs that a firm incurs when it enters an industry; industry size refers to the number of consumers that populate an industry; and product substitutability captures the extent to which the product of a firm can be replaced by the product of another firm due to similarities in how products look and function, in the conditions and terms of their use and sale, and in how buyers perceive them (Caves, 1971). Competition fundamentals likely have implications for the spillover effects of MD\&As for investments because they influence disclosures and investments, as we discuss next.

Theory implies that firms disclose more information when entry costs are lower, because rivals that interpret non-disclosure as a signal of good news can more readily act on this interpretation (Darrough and Stoughton, 1990; Wagenhofer, 1990). Empirical studies confirm that firms disclose more information when entry costs are lower (Li, 2010b; Ellis et al. 2012; Li et al., 2018). For instance, more firms disclose management forecasts, with higher frequency, in markets with fiercer competition from potential entrants (Li, 2010b). Firms may, however, be biased in their disclosures when facing the threat of potential entrants, especially when there are few existing rivals (Li et al., 2013). In Section 6, we control for biased disclosures. Theory also implies that firms disclose more information in larger industries where the demand for products and services is higher. A higher demand attracts more firms into the industry (Bresnahan and Reiss, 1987), and each firm benefits to a larger extent from using disclosures to influence its rivals' strategic choices or to steer demand towards its own products (Stivers, 2004; Corona and Nan, 2013). Empirical evidence, however, suggests that disclosures can decline with the number of firms in an industry (Jin, 2005).

Finally, theory implies that firms disclose more information when products are less substitutable (Darrough, 1993; Raith, 1996; Clinch and Verrecchia, 1997). In industries with less substitutable products, revealing information does less harm to the disclosing firm's profits

\footnotetext{
${ }^{4}$ Products are substitutes when the cross-elasticity of a firm's demand with respect to the price charged by a rival is positive.
} 
since it is less likely that new entrants are attracted to the industry or that incumbents modify production decisions $5^{5}$ Empirical research is consistent with this prediction Guo et al. 2004; Bernard, 2016). Overall, our discussion implies that rivals disclose more information in their MD\&As, and that companies have more information available for making investment decisions, when they operate in industries that have lower entry costs and less substitutable products; it is unclear whether, in larger industries, there is more information available in MD\&As.

We now consider how companies invest, conditional on their information, including information from rivals' disclosures. Investment decisions are influenced by competition fundamentals, for two reasons. First, competition fundamentals shape strategic interactions in an industry and influence how companies make investment decisions in an effort to deter entry from new rivals, preempt or escape competition from existing rivals, or induce their exit. Studies that consider strategic interactions are ambiguous about how investment is associated with competition fundamentals. On one hand, when companies anticipate rivals' reactions, they can invest more when they operate in industries that have higher entry costs, are smaller, and have less substitutable products (De Bondt et al., 1992; De Bondt, 1996; Frésard and Valta, 2016). In such industries, rivals' reactions are tempered, and the reduction in a company's competitive advantage due to the leakage of information from investment is contained. On the other hand, companies may invest more in industries that have lower entry costs, are larger, and have highly substitutable products in an effort to increase entry barriers and differentiate products (Cellini and Lambertini, 2002; Aghion et al., 2005; Hoberg and Phillips, 2016).

Second, competition fundamentals matter beyond strategic interactions in an industry, since they are linked to a firm's demand and cost conditions. For instance, in industries with high entry costs, firms that wish to enter have to make substantial investments, which can increase their capacity to absorb and exploit information (Zahra and George, 2002). Also,

\footnotetext{
${ }^{5}$ The results of models that explore product substitutability are not always clear-cut and can depend on other parameters of the competitive environment, such as the type of competition (i.e., Cournot or Bertrand) (Darrough, 1993, Raith, 1996, Clinch and Verrecchia, 1997).
} 
larger industries may provide firms more opportunities for learning and for building capacity for learning; firms may have access to a broader base of potential research personnel and partners for forming strategic alliances or informal networks (Mowery et al., 1996; Almeida and Kogut, 1999). Finally, when products are close substitutes, firms have similar business operations and technologies; their employees have related skills and are likely to share a language (Chen, 1996).

Taken together, the strategic and non-strategic aspects of the investment process imply that a company's use of its rivals' MD\&As for investment decisions varies with competition fundamentals, and this variation is ambiguous. Accordingly, we do not make a directional prediction about how entry costs, industry size and product substitutability affect the association between a company's investments and the tone of its rivals' MD\&As. Our second hypothesis, stated in the alternate form, is as follows.

H2. Ceteris paribus, the association between a company's investments and the tone of its rivals' MD\&As varies with entry costs, industry size, and product substitutability.

Next, we consider the efficiency of a company's investments, and whether it is associated with the tone of its rivals' MD\&As. Ex ante, it is unclear whether the spillover effects of rivals' MD\&As for a company's investments are efficient and increase the company's value. Consider rivals that release good news in their MD\&As about an increase in demand. The company may invest more upon learning this news. This additional investment can be efficient when the good news in rivals' MD\&As provides the company with new information about the uncertain NPVs of its investments (Durnev and Mangen, 2009). Yet, the additional investment may also be inefficient: managers who are entrenched or overconfident can use a rise in demand to justify investing in weak divisions or postponing divesting poorly performing assets (Scharfstein and Stein, 2000; Malmendier and Tate, 2005, Pan et al., 2016). Accordingly, we do not make a directional prediction about the association between the efficiency of a company's investments and the tone of its rivals' MD\&As. Our third hypothesis, stated in the alternate form, is as follows.

H3. Ceteris paribus, the efficiency of a company's investments is associated with the tone of its rivals' MD\&As. 
Finally, we consider how competition fundamentals influence the association between the efficiency of a company's investments and the tone of its rivals' MD\&As. As discussed above, competition fundamentals shape the information that firms disclose and the investment decisions that managers of other companies make with this information. Whether the resulting investments are efficient depends notably on managers' incentives, which are influenced in ambiguous ways by competition, as suggested by the following theoretical studies.

On one hand, more intense competition can provide stronger implicit incentives to managers by threatening the company's survival and constraining their slack (Hart, 1983; Schmidt, 1997). More intense competition can also result in stronger explicit incentives. For instance, when higher product substitutability leads to price drops and drives firms to exit, the remaining companies produce larger output, which encourages them to reduce costs by giving managers stronger compensation-based incentives (Raith, 2003). On the other hand, more intense competition can lead to weaker implicit or explicit managerial incentives (Scharfstein, 1988; Raith, 2003). For example, when entry costs decline and new firms enter an industry, firm-level output declines, which encourages companies to decrease managers' compensationbased incentives (Raith, 2003).

Empirical studies suggest that firms provide stronger explicit compensation-based incentives to managers when competition is more intense (e.g., entry costs are lower) Karuna, 2007; Cuñat and Guadalupe, 2009). In parallel, empirical research shows that governance mechanisms other than executive pay are associated with competition (Giroud and Mueller, 2011). Overall, this discussion indicates that competition fundamentals can have ambiguous effects on the association between the efficiency of a company's investments and its rivals' MD\&A tone. We do not make a directional prediction about how this association varies with entry costs, industry size, and product substitutability. Our last testable prediction, stated in the alternate form, is as follows.

H4. Ceteris paribus, the association between a company's investment efficiency and the tone of its rivals' MD\&As varies with entry costs, industry size, and product substitutability. 


\section{Sample, Data and Variable Definition}

\subsection{Sample and Data}

Table 1 shows sample selection details. Our sample starts with 142, 843 firm-years $(20,897$ firms) with data available for computing the main variables between 1996 (when most firms filed their 10-Ks electronically with the SEC via EDGAR) and 2016. We discard observations with fiscal year changes, which leaves 128, 736 firm-years (17, 182 firms); we remove financials (SIC 6000 to 6999) and utilities (SIC 4900), which yields 108, 554 firm-years (14, 164 firms). We manually collect 10-Ks via EDGAR using tickers and firm names from COMPUSTAT. We drop 48, 177 observations for which EDGAR searches produce no results, yield text files with missing MD\&A sections, or give MD\&A sections with fewer than 2,000 words that, upon inspection, are not readable or contain mistakes. Our final sample has 60,377 firm-years (8, 870 firms). Stock market data are from CRSP and accounting data from COMPUSTAT.

Rivals of a company are defined as all firms that operate in the same industry as the company, excluding the company. To identify industries, we use the 3-digit Standard Industry Classification (SIC) codes, consistent with prior research (Beatty et al., 2013). SIC codes put firms into pre-defined categories based on production processes, and they are fairly stable over time. Our sample has an average of 213 3-digit SIC industries per year. Each company has, on average, 18 disclosing rivals in its 3-digit SIC code and is the rival of at least one other firm. As an alternative to SIC codes, we identity industries using the classification of Hoberg and Phillips (2010, 2016); our results hold, as discussed in Section 6 .

\subsection{Variable Definition}

We calculate Investment as capital expenditures (COMPUSTAT: CAPX) plus R\&D expenditures (COMPUSTAT: XRD) and acquisitions (COMPUSTAT: AQC) minus cash receipts from sales of property, plant, and equipment (COMPUSTAT: SPPE) multiplied by 100, all scaled by lagged total assets (COMPUSTAT: AT). Table2 shows that average Investment is $16.43 \%$ of lagged total assets and varies from a 25 th percentile of $7.05 \%$ to a 75 th percentile of $17.69 \%$.

We measure Investment ef ficiency following Biddle et al. (2009) and estimate, in the 
pooled cross-section, a regression of a company's year $t$ investment on sales growth between $t-2$ and $t-1 .^{6}$ The absolute value of a residual from this regression captures the deviation in the company's investment from expected investment driven by sales growth. A smaller deviation (and a lower absolute value of the residual) suggests more efficient investment. We define Investment efficiency as minus one times the absolute value of the residual; larger values of Investment ef ficiency denote more efficient investment.

To measure the Tone of MD\&As, we proceed as follow. From the 10-K of each firm-year, we extract the MD\&A section; we remove tables, figures, business descriptions, and "safe harbor" paragraphs that protect against litigation. We retain the remaining MD\&A section, whose length ranges from a minimum of 1,716 words to a maximum of 32,388 words; the average length is 10,050 words. For each firm-year, we process MD\&A sentences using the 2018 version of the word list from Loughran and McDonald (2011) to obtain their Tone, which is the number of positive words minus the number of negative words, per 100 words in sentences in each MD\&A.7 The Loughran McDonald word list has been developed for the business context, unlike other word lists such as Diction (Loughran and McDonald, 2015); it contains 354 positive words and 2,355 negative words. Rivals' tone is, for each company-year, the average, across all the company's rivals, of each rival's Tone. Panel B of Table 2 shows that rivals' MD\&As are more pessimistic than optimistic: average (median) tone is -0.763 $(-0.782) \cdot{ }^{8}$

We measure Competition using three variables computed at the level of the 3-digit SIC

\footnotetext{
${ }^{6}$ We use non-missing data from COMPUSTAT between 1996 and 2016; the intercept of our regression is 0.058 ( $t$-statistic: 112.55 ), the coefficient on the percentage change in sales is 0.021 ( $t$-statistic: 22.18 ), and the adjusted $R^{2}$ is $1.29 \%$.

${ }^{7}$ The 2018 version of the Loughran and McDonald word list is available at https://sraf.nd.edu/[dataset] Loughran and McDonald, 2018).

${ }^{8}$ To see how we calculate these descriptive statistics, consider companies X, Y, Z, V, and W. Company $\mathrm{X}$ has two rivals, $\mathrm{Y}$ and $\mathrm{Z}$. To calculate the tone that $\mathrm{X}$ faces, we compute the average of the tone of the MD\&A of each $\mathrm{Y}$ and $\mathrm{Z}$; call this average A. Company $\mathrm{Y}$ has two rivals, $\mathrm{X}$ and $\mathrm{Z}$; the tone it considers is the average of the tone of the MD\&A of each $\mathrm{X}$ and $\mathrm{Z}$; call this average $\mathrm{B}$. Company $\mathrm{Z}$ has rivals $\mathrm{X}$ and $\mathrm{Y}$; the tone it takes into account is the average of the tone of the MD\&A of each X and Y; this average is $\mathrm{C}$. Company $\mathrm{V}$ has as a rival company $\mathrm{W}$; the tone it faces is the tone of the MD\&A of W; let this tone be D. Finally, company $\mathrm{W}$ has as a rival V; the tone it considers is the tone of the MD\&A of V; call this tone E. The summary statistics in Table 2 are the means, standard deviations, minima, 25th percentiles, medians, 75th percentiles, and maxima across observations A, B, C, D, and E.
} 
code (excluding the investing company): (1) Entry costs, (2) Industry size, and (3) Product substitutability. Entry costs are calculated as the natural logarithm of the weighted mean of the gross value of cost of PP\&E of each firm in the industry, the weights being each firm's industry market share. PP\&E proxies for physical investments required to enter an industry; larger physical investments discourage entry. Industry size is the natural logarithm of total industry sales (Karuna, 2007). Prior research has used data on populations to measure industry size (Bresnahan and Reiss, 1987); we do not have such data available for our 3-digit SIC industries. Product substitutability is the ratio of an industry's total operating costs (the sum of cost of goods sold; selling, general, and administrative expenses; and depreciation, depletion, and amortization) to its total sales (Karuna, 2007). Larger values of this ratio proxy for higher product substitutability. The ratio represents the inverse of the price-cost margin. When products are more substitutable, the price-cost margin is lower since firms are unable to charge higher prices without losing customers. Table 2 shows descriptive statistics for the three competition variables.

\section{Results for investment}

We use the following regression to analyze the spillover effects of MD\&A tone for investment:

$$
\begin{aligned}
\text { Change in investment }= & \alpha+\beta \text { Change in rivals' tone }+\Gamma \text { Competition } \times \text { Change in rivals } \text { 'tone }^{\prime} \\
& +\Lambda \text { Competition }+\Theta \text { Change in control variables }+\varepsilon,
\end{aligned}
$$

where Change in investment is the change, between $t+1$ and $t$, in a company's Investment; Change in rivals' tone is the change, between $t$ and $t-1$, in the Tone of its rivals' MD\&As; and Competition includes the three competition fundamentals, Entry costs, Industry size, and Product substitutability. When Competition is not included in regression (1), the coefficient on Change in rivals' tone captures the association between the company's investment and the tone of its rivals' MD\&As. H1 predicts that this association is significantly different from zero. When Competition is included in regression (1), the coefficient on Competition $\times$ Change in rivals tone shows how the association between the company's investment and the tone of its rivals' MD\&As is affected by Entry costs, Industry size, and Product substitutability. $\mathrm{H} 2$ predicts that this effect is significantly different from zero. 
We control for factors other than rivals' MD\&A tone that can be associated with investment. A first set of factors accounts for information sources that can offer news for investment decisions: rivals' investment (De Bondt, 1996), the company's and its rivals' stock price informativeness and their analyst earnings forecasts, the company's stock returns during the prior 12 months, and its abnormal returns at its rivals' prior-year earnings announcements (Chen et al. 2007) $9^{9}$ A second set of factors controls for investment opportunities: the company's and its rivals' Tobin's Q, and the company's MD\&A tone (Bryan, 1997; Foucault and Fresard, 2014). We discuss measurement error in Tobin's Q in Section 6. Finally, we account for financing considerations, since rivals' disclosures can have implications for the company's cost of capital (Biddle et al. 2009; Shroff et al., 2017). We use the following proxies: the company's cash, which affects its ability to fund investment and over-invest (Malmendier and Tate, 2005; Denis and Sibilkov, 2010); its financial constraints, which hinder the funding of investment opportunities; and its total assets, which influence access to capital markets (Hennessy and Whited, 2007). Also controlling for financing considerations are rivals' investments, which can have implications for the company's financial structure (MacKay and Phillips, 2005), and the company's stock returns during the prior 12 months, which can affect market timing when companies raise capital (Bolton et al., 2013). Table 2 shows summary statistics for these three sets of factors.

We use first differencing in regression (1) to account for unobservable non-varying firm characteristics. We include year fixed effects to control for time factors (e.g., market sentiment, industry shocks, and changes in regulation). We cluster standard errors by 3-digit SIC code to account for potential time-series error correlation; standard errors are robust to heteroscedasticity. We winsorize all variables at the $1 \%$ and $99 \%$ levels; our results hold without winsorizing.

We report our findings from estimating regression (1) in Table 3 . Consistent with H1, the results in model 3 show that the estimated coefficient on Change in rivals ${ }^{\prime}$ tone is significantly different from zero; it is positive, at 0.148 ( $t$-statistic: 5.20 ), suggesting that a company invests more when its rivals are more optimistic in their MD\&As. Economically,

\footnotetext{
${ }^{9} \mathrm{We}$ focus on earnings announcements from the year before the release of the $t-110-\mathrm{Ks}$ that include the MD\&As we examine.
} 
this evidence indicates that when Change in rivals' tone increases by one standard deviation (3.08, undisplayed), Change in investment increases by $0.148 \times 3.08=0.456$, or 45.6 cents per $\$ 100$ of assets. To put this result in perspective, we turn to Tobin's $Q$. The coefficient on Change in company's Tobin's $Q$ in model 3 is positive at 0.350 (t-statistic: 3.58$)$. When the Change in company's Tobin's $Q$ increases by one standard deviation (1.208, undisplayed), Change in investment increases by $0.350 \times 1.208=0.423$, or 42.3 cents per $\$ 100$ of assets. The economic significance of Tobin's $Q$ is $7 \%$ lower than that of rivals' MD\&A tone.

Model 4 in Table 3 includes competition fundamentals and shows that the spillover effects of MD\&As vary with entry costs, industry size, and product substitutability. The coefficient on the interaction between Entry costs and Change in rivals' tone is significantly negative at -0.192 ( $t$-statistic: -4.28$)$, suggesting that the association between a company's investments and the tone of its rivals' MD\&As is stronger when their industry has lower entry costs. The interaction between Industry size and Change in rivals' tone yields a coefficient that is significantly positive at 1.882 ( $t$-statistic: 6.12 ), indicating that a company's investments have a stronger association with the tone of rivals' MD\&As when their industry is larger. Finally, the coefficient on the interaction between Product substitutability and Change in rivals ${ }^{\prime}$ tone is significantly negative at -0.082 ( $t$-statistic: -2.45$)$, suggesting that the association between a company's investments and the tone of its rivals' MD\&As is stronger when product substitutability is lower. Our analysis in Table 3 controls for factors other than rivals' MD\&A tone that can be associated with a company's investments: information from sources other than rivals' MD\&As, investment opportunities, and financing considerations. We find that proxies for these three sets of factors are significantly associated with investment.

Comparing model 3 and model 4 to model 1, which does not include Change in rivals tone, reveals how adding Change in rivals' tone modifies the coefficients on other variables. Overall, there are no substantial changes in these coefficients, except for the coefficients on two variables. First, the coefficient on the Change in company's tone drops from 0.216 ( $t$-statistic: 4.25$)$ in model 1 to 0.108 ( $t$-statistic: 1.94) in model 3, and it rises again to 0.144 (t-statistic: 4.16) in model 4. Second, the estimated coefficient on the Change in

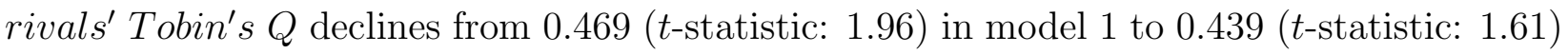
in model 3, and it becomes significant again in model 4 at 0.400 ( $t$-statistic: 1.91). These 
results suggest that Change in rivals' tone captures some but not all of the information relevant for the company's investments that is included in Change in company's tone and in Change in rivals' Tobin's $Q$.

The coefficient on Change in rivals' investment is of interest because rivals' investments can have substantial spillover effects for the company's investment (De Bondt, 1996). We find in model 1, where Change in rivals ${ }^{\prime}$ tone is not included, that the coefficient on the Change in rivals ${ }^{\prime}$ investment is significantly positive at 0.377 ( $t$-statistic: 18.26$)$; in model 3 where Change in rivals' tone is included, the coefficient on Change in rivals' investment is smaller, at 0.256 , but still statistically significant at the $1 \%$ level ( $t$-statistic: 15.45$)$, as it is in model 4 , at 0.261 ( $t$-statistic: 15.18 ). This evidence suggests that the tone of rivals' MD\&As proxies for some, but not all, of the information in rivals' investment. Our evidence indicates that rivals' investment, similarly, proxies for some, but not all, of the information in rivals' MD\&A tone. In model 2, where the Change in rivals' investment is not included, the coefficient on Change in rivals' tone is 0.258 ( $t$-statistic: 5.86 ). When the Change in rivals' investment is added in model 3, the coefficient on Change in rivals ${ }^{\prime}$ tone declines to 0.148 but remains significant at the $1 \%$ level ( $t$-statistic: 5.20). From an economic perspective, the coefficient on Change in rivals' investment is significant: in model 3, a one-standard-deviation rise in the Change in rivals' investment (14.22, undisplayed) is associated with an increase in Change in investment of $0.256 \times 14.22=3.64$, or $\$ 3.64$ per $\$ 100$ of assets, which is about eight times larger than the Change in investment associated with a one-standard-deviation increase in the Change in rivals' tone documented above.

In further tests, we evaluate the role of benchmarks for rivals' MD\&A tone. Benchmarks capture managers' priors against which they evaluate rivals' MD\&A tone. Research suggests that zero may act as a benchmark, and that investor reactions may be stronger for negative MD\&A tone than for positive MD\&A tone (Tetlock, 2007; Tetlock et al., 2008; Kuhnen, 2015). Individuals more readily process negative information than positive information (Tetlock et al., 2008, Kuhnen, 2015), and positive language is less credible than negative language, since managers may benefit from positive language more than from negative language (Lang and Lundholm, 2000; Hutton et al., 2003). We consider four benchmarks for tone: zero, the tone of rivals' MD\&As in $t-1$, the tone of rivals' MD\&As between $t-6$ and $t-2$, and the 
tone of the investing company's MD\&As. Table 1 in the Online Supplement suggests that all four benchmarks are relevant, and that the association between a company's investments and its rivals' MD\&A tone is weaker when tone is positive or higher than prior-year tone.

We also evaluate the role of benchmarks for a company's investment, which capture the investment that managers would have undertaken absent any news in the tone of rivals' MD\&As. We do not have a prior regarding investment benchmarks, since they are unobservable and depend on managerial decision-making processes. We proxy for investment benchmarks using zero investment, the company's $t-1$ investment, and its average investment between $t-6$ and $t-2$. We analyze whether the company's investment, relative to each benchmark proxy, is associated with its rivals' MD\&A tone. Table 2 in the Online Supplement shows that all three benchmark proxies play a role: investment relative to each benchmark proxy is significantly associated with rivals' MD\&A tone.

Finally, we explore the role of disclosures. Our arguments in Section 2 about how industry competition shapes the spillover effects of disclosures are not limited to MD\&A disclosures but apply to other disclosures as well. Accordingly, we investigate whether our industry competition results hold for disclosures other than MD\&As. To focus on industry competition, we use disclosures for which spillover effects have already been documented - that is, restatements of financial reports (Durnev and Mangen, 2009). We explore how industry competition moderates the spillover effects of information in restatement disclosures. We use two proxies for this information: the cumulative abnormal returns that restating rivals experience from the five days before the restatement announcement to the five days thereafter, following Durnev and Mangen (2009), and the tone of the press release that announces the restatement, where tone is measured as described in Section 3.2. We obtain data on restatements from the General Accounting Office for restatements between 1996 and 2005, and from Business Analytics for restatements between 2006 and 2016. Our restatement sample includes a total of 3,980 restatements by 2,599 firms. Because press releases are missing for some restatements, our sample for the analysis of the tone of restatement press releases is smaller and includes 3,202 restatements by 2,227 firms. We find that our results hold. As shown in Table 3 in the Online Supplement, the spillover effects of information in restatement disclosures are stronger, both for investment and investment efficiency, when entry costs are 
lower, industry size is larger and products are less substitutable. The results for product substitutability are significant only when information in restatement disclosures is measured using rivals' abnormal returns at the restatement announcement.

\section{Results for investment efficiency}

To analyze the spillover effects of MD\&A tone for investment efficiency, we update regression (1) as follows.

$$
\begin{aligned}
\text { Change in investment efficiency }= & \alpha+\beta \text { Change in rivals' }{ }^{\prime} \text { unsigned tone } \\
& +\Gamma \text { Competition } \times \text { Change in rivals }{ }^{\prime} \text { unsigned tone } \\
& +\Lambda \text { Competition }+\Theta \text { Change in control variables }+\varepsilon,
\end{aligned}
$$

where Change in investment efficiency is the change, between $t+1$ and $t$, in a company's Investment ef ficiency; Change in rivals' unsigned tone is the change, between $t$ and $t-1$, in the average, across all rivals, of the absolute value of the Tone of each rival's MD\&A. We use unsigned tone because it is not the sign of the tone that shapes investment efficiency (i.e., investment efficiency can increase when tone is positive or negative) but rather news in tone. Our analysis in Section 4 suggests that news in tone is evaluated by comparing MD\&A tone to the benchmark of zero. Accordingly, Change in rivals' unsigned tone proxies for the (good and bad) news in rivals' tone. Competition includes three measures of competition fundamentals, Entry costs, Industry size, and Product substitutability. When Competition is not included in regression (2), the coefficient on Change in rivals' unsigned tone captures the association between the company's investment efficiency and the unsigned tone of its rivals' MD\&As. H3 predicts that this association is significantly different from zero. When Competition is included in regression (2), the coefficient on Competition $\times$ Change in rivals ${ }^{\prime}$ unsigned tone shows how the association between the company's investment efficiency and the unsigned tone of its rivals' MD\&As is affected by Entry costs, Industry size, and 
Product substitutability. H4 predicts that this effect is significantly different from zero. ${ }^{10}$

Table 4 shows the results. Consistent with H3, model 3 reveals that the association between Change in investment efficiency and Change in rivals' unsigned tone is significantly positive at 0.084 ( $t$-statistic: 3.18 ). Economically, this evidence suggests that when Change in rivals' unsigned tone increases by one standard deviation (0.486, undisplayed), Change in investment efficiency increases by $0.084 \times 0.486=0.041$, or 4 cents per $\$ 100$ of assets. To put this result in perspective, we turn to Tobin's $Q$. The coefficient on the Change in company's Tobin's $Q$ in model 3 is positive at 0.112 (t-statistic: 3.93). When Change in company's Tobin's $Q$ increases by one standard deviation (1.208, undisplayed), Change in investment efficiency rises by $0.112 \times 1.208=0.135$, or 13.5 cents per $\$ 100$ of assets. The economic significance of Tobin's $Q$ is about three times higher than that of rivals' MD\&A tone; this being said, Tobin's $Q$ does not subsume the effect of rivals' MD\&A tone.

Model 4 in Table 4 shows how competition fundamentals influence the spillover effects of MD\&A tone for investment efficiency. We find that the association between the efficiency of a company's investments and rivals' unsigned MD\&A tone is stronger when the industry has lower entry costs; the coefficient on the interaction between Entry costs and Change in

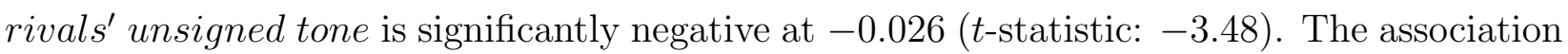
between the efficiency of a company's investments and its rivals' unsigned MD\&A tone is also stronger when the industry is larger; the coefficient on the interaction between Industry size and Change in rivals' unsigned tone is significantly positive at 7.812 (t-statistic: 6.21). Finally, the coefficient on the interaction between Product substitutability and Change in rivals' unsigned tone is negative, but insignificant, at -0.014 ( $t$-statistic: -0.38$)$. Our ev-

\footnotetext{
${ }^{10}$ We include control variables to account for other information sources that can provide news for investment decisions (via the company's and its rivals' stock price informativeness and their analyst earnings forecasts, the company's stock returns during the prior 12 months, its abnormal returns at rivals' earnings announcements, and rivals' investment) and for funds available to finance investment (via the company's cash, its financial constraints and its total assets), both of which are associated with investment efficiency (Durnev et al. 2004). We also control for investment opportunities, which can affect the quality of capital allocation (via the company's and its rivals' Tobin's $Q$ and the company's MD\&A tone). In a sensitivity test, we add the governance index from Gompers et al. (2003) as an explanatory variable to control for interest alignment between managers and shareholders. The estimated coefficient on the governance index is significantly positive, indicating that higher investment efficiency is associated with better governance.
} 
idence indicates that competition fundamentals pertaining to entry costs and industry size moderate the spillover effects of rivals' MD\&A tone for investment efficiency. Our analysis in Table 4 controls for factors other than MD\&A tone that can be associated with the efficiency a company's investments: information sources other than rivals' MD\&As, investment opportunities, and financing considerations. We find that proxies for these three sets of factors are significantly associated with investment efficiency.

To determine whether adding Change in rivals' unsigned tone modifies the estimated coefficients on other variables, we compare model 3 and model 4 to model 1, which does not include Change in rivals' unsigned tone. We find that coefficients on other variables remain fairly stable, except for the coefficient on Change in rivals' investment. Model 1 shows that the coefficient on the Change in rivals' investment is significantly positive at $0.062(t$ statistic: 1.98); in model 3 and model 4, the coefficient on the Change in rivals' investment is smaller and not statistically significant, at 0.035 with $t$-statistic of 1.05 (model 3) and at 0.050 with $t$-statistic of 1.50 (model 4 ). This result suggests that rivals' MD\&A tone subsumes the effect of rivals' investment. This may happen because rivals' MD\&As offer a more informative signal than their investments for a company's investment decision process. Supporting this interpretation is evidence on how the coefficient on Change in rivals' unsigned tone is altered when Change in rivals' investment is added to the regression. In model 2, which does not include Change in rivals' investment, the coefficient on Change in rivals' unsigned tone is significantly positive at 0.208 (t-statistic: 6.12). In model 3, which includes Change in rivals' investment, the coefficient on Change in rivals' unsigned tone is smaller, at 0.084, yet remains highly significant, with a $t$-statistic of 3.18 .

Investments are more efficient when companies over-invest less and/or under-invest less. We analyze whether the association between the efficiency of a company's investments and its rivals' unsigned MD\&A tone is driven by over- and/or under-investment, which we identify following Biddle et al. (2009). We sort into quartiles the signed residuals from a regression of a company's year $t$ investment on sales growth between $t-2$ and $t-1$. Residuals in the bottom quartile, which are the most negative, represent under-investment, whereas residuals in the top quartile, which are the most positive, represent over-investment. Residuals in the two middle quartiles represent normal investment. We construct a categorical variable 
Categories of investment, whose three categories are over-investment residuals, normal investment residuals, and under-investment residuals. We use maximum likelihood estimation to fit a multinomial logistic model that predicts the probability that residuals are in the middle category instead of in the top or bottom categories; the dependent variable in this model is Probability (Categories of investment) and the independent variable of interest is Change in rivals' unsigned tone. Table 4 in the Online Supplement shows that our results in Table 4 are driven by reductions in over-investment: when the unsigned tone of rivals' MD\&As is larger, companies are more likely to invest normally than to over-invest.

A manager may invest when he or she believes that other managers are optimistic, and he or she reflects beliefs regarding optimism in his/her firm's MD\&A. Based on this MD\&A, other managers may invest more. Such feedback loops can result in inefficient investment. We examine whether investment based on MD\&A tone is efficient by examining how the efficiency of a company's investments is associated with investments predicted from its rivals' MD\&A tone. As shown in Table 5 in the Online Supplement, investments are more efficient when a company invests more based on its rivals' MD\&A tone. This result suggests that investments associated with rivals' MD\&As are efficient rather than inefficient.

So far, we have proxied for investment efficiency using the measure developed in Biddle et al. (2009). As an alternative, we follow Ferreira and Laux (2007) and take the absolute value of the residuals from a regression of the change in the company's equity value on the change in its net fixed assets ${ }^{11}$ Larger absolute values of residuals indicate less efficient investment. Undisplayed results show that our findings in Table 4 hold. The investment efficiency measures from Biddle et al. (2009) and Ferreira and Laux (2007) rely on residuals from first-stage regressions. When the residual from a first-stage regression is used as a dependent variable in a second-stage regression, the estimated second-stage regression coefficients can be biased towards zero or away from zero depending on the correlation between second-stage control variables and first-stage regressors (Chen et al., 2018). Accordingly, we analyze whether our investment efficiency measure may have introduced bias into our results. Following the recommendation in Chen et al. (2018), we refrain from using a two-stage

\footnotetext{
${ }^{11}$ We estimate this regression in the pooled cross-section without industry effects to avoid spurious relations with our industry-based MD\&A tone measures.
} 
model for our investment efficiency analysis and instead rely on the following three one-stage regression models.

First, we use the conditional model in Biddle et al. (2009) to estimate the following regression: Change in investment $=\alpha+\beta_{1}$ Change in rivals' unsigned tone $+\beta_{2}$ Over Investment $+\beta_{3}$ Over Investment $\times$ Change in rivals' unsigned tone $+\Theta$ Change in control variables $+\varepsilon$, where control variables are defined as in regression (1). The variable Over Investment, which captures the likelihood that a company over-invests, is calculated following Biddle et al. (2009). We rank firms into deciles based on their cash balance and on their debt (multiplied by minus one), we rescale each ranked variable so that it ranges from zero to one, and we compute the average of the ranked variables to obtain Over Investment. The coefficient $\beta_{1}$ captures the association between a company's investment and its rivals' unsigned MD\&A tone when underinvestment is most likely. Following H3, this coefficient is expected to be significantly different from zero. The sum of $\beta_{1}$ and $\beta_{3}$ captures the association between the company's investment and its rivals' unsigned MD\&A tone when over-investment is most likely. H3 implies that this sum is significantly different from zero. Table 6 in the Online Supplement shows that $\beta_{1}$ is significantly positive at 0.612 ( $t$-statistic: 4.18$)$. This result is consistent with $\mathrm{H} 3$ and implies that the association between a company's investment and the unsigned tone of its rivals' MD\&As is stronger when under-investment is most likely. The coefficient $\beta_{3}$ is significantly negative at -3.440 ( $t$-statistic: -5.29$)$. The sum of $b_{1}+b_{3}$, which gives the overall effect of rivals' unsigned MD\&A tone on a company's investment, is significantly negative, as indicated by the Wald test. This finding, which is consistent with H3, suggests that the association between a company's investment and the unsigned tone of its rivals' MD\&As is weaker when over-investment is most likely.

Second, we use bidders' abnormal returns at acquisition announcements, following Francis and Martin (2010). Higher bidder abnormal returns proxy for larger investment efficiency. Abnormal returns are cumulative market-adjusted returns measured from three days before an acquisition announcement to three days thereafter, and market returns are given by the CRSP value-weighted index. We identify 7,616 completed acquisitions and their announcement dates from the SDC Mergers and Acquisitions database between 1996 and 2016. We estimate a regression where the dependent variable is a bidder's abnormal returns at an acqui- 
sition announcement. The explanatory variable of interest is its rivals' unsigned MD\&A tone; control variables are the same as in regression (2). Table 7 in the Online Appendix shows that our findings hold. The association between a bidder's abnormal announcement returns and its rivals' unsigned MD\&A tone is significantly positive at 1.144 ( $t$-statistic: 6.12$)$. The association is stronger when entry costs are lower, industry size is larger, and products are less substitutable. Finally, we proxy for investment efficiency using the company's performance measures, including return on investment, economic value added, total factor productivity, and return on equity (Francis and Martin, 2010; Glaser et al., 2013). Our results hold. For example, when the dependent variable is total factor productivity, the coefficient on Change in rivals' unsigned tone is 0.612 ( $t$-statistic: 4.29$)$.

\section{Additional tests}

We perform a series of additional tests that we detail below.

\subsection{Common and firm-specific disclosures}

Theoretical disclosure studies often distinguish between two types of disclosures: disclosures common to the industry where the disclosing firm operates, which provide insights about profit parameters common to all firms in the industry (e.g., demand), and disclosures specific to the disclosing firm, which offer insights about its own profit parameters (e.g., production costs) (Wagenhofer, 1990; Darrough, 1993; Raith, 1996). Companies may invest differently depending on the type of disclosures in their rivals' MD\&As. Consider common disclosures in a rival's MD\&A. Good news in common disclosures (e.g., increase in industry demand) represents good news for other companies in the industry; their managers may revise upwards their investments' NPVs and invest further. Now consider firm-specific disclosures in a rival's MD\&A. Good news in firm-specific MD\&A disclosures (e.g., decrease in the rival's production costs) can represent bad news for other companies in the industry; their managers revise downwards their investments' NPVs and reduce investments. Good news in firm-specific MD\&A disclosures can also signal to other companies that they have deficiencies in their operations that need addressing or that there are opportunities for improving their operations that they have not yet considered; their managers may modify investment plans, revise upwards their investments' NPVs, and increase investment. This discussion suggests that 
common and firm-specific disclosures in rivals' MD\&As can have different implications for a company's investment. Accordingly, we analyze how the association between a company's investment and its rivals' MD\&A tone varies depending on whether MD\&A text is common or firm-specific.

We identify common and firm-specific MD\&A text as follows. For each firm and year, we determine its main products (e.g., Windows for Microsoft), businesses (e.g., Microsoft Business Solutions), and industry (e.g., information technology, online services) from the business descriptions in the $10-\mathrm{K} \cdot \sqrt{12}$ We thus obtain keywords characterizing its products, businesses, and industries. We split keywords into two lists: a firm-specific list (i.e., keywords referring to products and businesses) and a common list (i.e., keywords referring to industries). Common and firm-specific keyword lists are uploaded into Python, which draws on these lists to count common and firm-specific words in every sentence of each MD\&A. On average, the number of common (firm-specific) words is 6,070 (4,220) per MD\&A. We classify an MD\&A sentence as common (firm-specific) if it contains at least one common (firm-specific) keyword; $70 \%$ of MD\&A sentences contain either common or firm-specific words, while the remaining $30 \%$ contain both types of words or none of them. In the latter two cases, the sentence, as well as the two preceding and following sentences, is read to classify it either as common or firm-specific based on the interpretation from the reading. Our results hold if we discard MD\&A sentences with both common and firm-specific keywords or without keywords.

Below, we provide examples of common and firm-specific MD\&A sentences using an excerpt from Microsoft's 2004 MD\&A. Keywords referring to common (firm-specific) information are in italics (bold).

We estimate growth in PC shipments was 13\% during fiscal 2004, reflecting global economic improvement, which led to strength in the consumer segment in the first half of fiscal 2004 and to replacement PC and notebook sales in the enterprise segment in the second half of fiscal 2004. In fiscal 2005, we do not expect revenue to grow at similarly high rates as fiscal 2004, even if information technology spending continues

\footnotetext{
${ }^{12}$ Item 101 of Regulation S-K requires that firms describe significant products and update descriptions each fiscal year.
} 
to improve. While we expect general economic conditions to remain stable with the improvements seen in the second half of fiscal 2004, we expect PC and server unit shipment growth rates to decline in fiscal 2005 from the high growth rates in fiscal 2004. We expect emerging markets to continue to outpace mature market growth rates and we expect to hold our share in these respective markets. If overall market demand for PCs, servers, and other computing devices declines significantly, or consumer or corporate spending for such products declines, our revenue will be adversely affected.

Some sentences in this excerpt contain common and firm-specific keywords; they are classified as common sentences based on the procedure outlined above. The next excerpt from the same 2004 Microsoft MD\&A provides only firm-specific information.

We estimate that overall server hardware shipments grew $16 \%$ in fiscal 2004 compared to the prior year. Server and Server applications revenue, including CAL revenue, grew $\$ 1.28$ billion or $25 \%$ driven primarily by an estimated $18 \%$ increase in Windowsbased server shipments resulting in $15 \%$ growth in new Windows Server licenses, and by favorable conversion of revenue billed in foreign currencies to U.S. dollars. Consulting and Premier product support services revenue increased $\$ 189$ million or $19 \%$ compared to fiscal 2003 due to increased customer penetration from new product offerings. Revenue from developer tools, training, certification, and Microsoft Press and other services declined $\$ 128$ million or $14 \%$ compared to fiscal 2003 due to recognition of revenue deferred in prior years. Foreign exchange rates contributed approximately $\$ 350$ million or $5 \%$ of Server and Tools revenue growth.

We evaluate the tone of common and firm-specific disclosures using the 2018 version of the word list from Loughran and McDonald (2011). Panel B of Table 2 shows that rivals' common and firm-specific disclosures are pessimistic more than optimistic. The average tone of rivals' common (firm-specific) MD\&A disclosures is $-0.790(-0.824)$. Returning to our Microsoft example, we find that its MD\&A is pessimistic more than optimistic: the tone of common (firm-specific) sentences is $-0.700(-0.769)$. The Online Supplement provides further details on how we compute common and firm-specific disclosures in Microsoft's 2004 MD\&A and on how we calculate their tone 13

\footnotetext{
${ }^{13}$ Our dataset that contains, for each firm-year, the tone of the complete MD\&A, the tone of its firmspecific sentences, and the tone of its common sentences is available at http://www.concordia.ca/content/ dam/jmsb/docs/research/researchdata/2019-durnev-mangen-data.xlsx ([dataset] Durnev and Mangen,2019).
} 
We estimate our regressions for investment and investment efficiency separately for common and firm-specific MD\&A disclosures. The results are displayed in Table 5, in models 1, 2, $3(4,5,6)$ for common (firm-specific) MD\&A disclosures. Panel A shows the findings for investment. For common and firm-specific MD\&A text, the association between Change in investment and Change in rivals' tone is significantly positive, at 0.222 (t-statistic: 4.74$)$ for common text in model 2 and at 0.198 ( $t$-statistic: 4.56 ) for firm-specific text in model 5 . The findings in models 3 and 6 suggest that competition fundamentals moderate the spillover effects of rivals' common and firm-specific MD\&A text. Model 3 shows that the association between a company's investment and the tone of its rivals' common text is significantly stronger when the industry is larger and products are less substitutable; model 6 indicates that the association between a company's investment and the tone of rivals' firm-specific text is significantly stronger when the industry is larger, products are less substitutable, and entry costs are lower.

Panel B in Table 5 displays the results for investment efficiency. For common and firmspecific text, the association between Change in investment efficiency and Change in rivals' unsigned tone is significantly positive at 0.314 (t-statistic: 6.23 ) for common text in model 2 and at 0.261 ( $t$-statistic: 5.08) for firm-specific text in model 5. The findings in models 3 and 6 indicate that competition fundamentals influence spillover effects of common and firm-specific MD\&A text. For common and firm-specific text, the association between the efficiency of a company's investments and its rivals' unsigned MD\&A tone is stronger when entry costs are lower and the industry is larger.

Overall, the evidence in Table 5 indicates that both common and firm-specific MD\&A disclosures have positive spillover effects for investment and investment efficiency and that competition fundamentals moderate these spillover effects.

\subsection{Forward-looking MD\&A disclosures}

Li (2010a) documents that forward-looking statements in a firm's MD\&As are associated with subsequent performance, which suggests that our results may be driven by forward-looking statements in rivals' MD\&As. To analyze this possibility, we separate rivals' MD\&As into forward-looking and non-forward-looking text. We identify forward-looking text as sentences 
containing at least one phrase indicative of the future from the following list: will, shall, want, desire, aspire, wish for, is going, are going, future, forthcoming, expect, predict, anticipate, wait for, look ahead to, forward-looking. These sentences are read to ascertain their futureoriented nature. Sentences neither future-oriented nor containing words from our list are classified as non-forward-looking. We use the 2018 version of the word list from Loughran and McDonald (2011) to obtain the tone of forward-looking and non-forward-looking sentences. We re-estimate regressions (1) and (2) with two new variables, one for the tone of forwardlooking MD\&A sentences and one for the tone of non-forward-looking sentences. Undisplayed results show that forward-looking and non-forward-looking MD\&A text have spillover effects for investment and investment efficiency. The coefficients on the tone of forward-looking MD\&A text are significantly larger than those on the tone of non-forward-looking MD\&A text.

\subsection{Bias in MDEGA disclosures}

Research cautions that firms can bias disclosures (Beatty et al., 2013; Li et al., 2013). Managers with rational expectations anticipate bias in rivals' disclosures and adjust how they use disclosures when they make investment decisions. Disclosures are likely more truthful when rivals are more credible, for instance, when they incur costs for subsequent actions that deviate from earlier disclosures (Corona and Nan, 2013). We expect that MD\&As of more credible rivals have larger spillover effects. We measure rivals' credibility as the accuracy of rivals' prior-year management earnings forecasts, defined as the absolute value of the difference between the rival's management forecast for its $t-1$ EPS and the actual $t-1$ EPS, averaged across all rivals and multiplied by negative unity (Mercer, 2004). Our results hold when we include rivals' credibility in our regressions. Moreover, we find that the spillover effects of rivals' MD\&As for investment and investment efficiency are larger when rivals are more credible.

\subsection{Alternative word lists}

We complement our analysis with two alternative word lists: the General Inquirer (Tetlock et al., 2008), which relies on the Harvard-IV-4 psychosocial dictionary, and Diction. These two word lists have been widely used. However, they are problematic because, unlike the 
word list from Loughran and McDonald (2011), they are not tailored to business settings and can misclassify optimistic words as pessimistic (Loughran and McDonald, 2016). Our results hold.

\subsection{Alternative definition of rivals}

We identify a company's rivals as all other firms operating in its 3-digit SIC code. SIC codes classify firms based on pre-defined categories developed from production processes. SIC codes have the advantage of readily identifying rivals. Yet, they may also introduce errors into the rival identification process, as they are only rarely updated and may not capture changes in rival composition over time. They can also fail to capture relatedness between firms in different industries that arises when firms with different production processes offer similar products. To address these concerns, we re-estimate our regressions using the fixed industry classification (FIC) from Hoberg and Phillips (2010, 2016), ${ }^{14}$ FIC codes classify firms into categories based on the similarity of product descriptions in 10-K business descriptions; they provide a measure of relatedness between rivals that focuses on products and not on production processes. If firms change product descriptions over time, FIC codes can reassign them into different industries. Our findings hold.

\subsection{Unmodeled investment opportunities}

Our tone variables may proxy for unmodeled investment opportunities, a concern we address in two ways. First, we split our sample based on the size of R\&D expenditures, since one of our proxies for investment opportunities, Tobin's $Q$, may be mismeasured in high R\&D industries. If our tone variables capture measurement error in Tobin's $Q$, our results should be stronger for high than for low R\&D observations. An observation belongs to the high (low) $R \& D$ subsample if the ratio of $R \& D$ expenditures to total assets is higher (lower) than the industry average. Our results are not statistically different for high and low R\&D subsamples.

Second, we apply the errors-in-variables regression approach from Erickson and Whited (2000, 2002). They show how, when there is measurement error in Tobin's $Q$ and OLS es-

\footnotetext{
${ }^{14}$ We use the code called "FIC-300," which roughly corresponds (by the average number of industries) to the 3-digit SIC classification. There are 224 FIC industries in our sample. Each company has, on average, 17 rivals in its FIC industry, with a minimum of 2 and a maximum of 307.
} 
timation is used, the coefficient on $Q$ can be understated and coefficients on other variables can be overstated. To address these problems, they propose a method-of-moments estimation that requires specifying that some variables are measured without error and others are measured with error (e.g., Tobin's $Q$ ). We follow their approach and estimate a first regression that consists of equation (1) from which we have removed the two tone variables, Change in rivals' tone and Change in investing company's tone. We specify that all variables in this regression, except for the two Tobin's $Q$ variables, are measured without error. We estimate a second regression that consists of equation (1); we specify that the two tone variables and the two Tobin's $Q$ variables are measured with error. We estimate the two regressions using the method-of-moments estimation from Erickson and Whited (2000, 2002) and our OLS estimation. Two results suggest that, after we account for measurement error, our tone measures are significant determinants of investment. First, when we use the methodof-moments estimation, the coefficient of determination is larger when the two tone measures are included in the regression. Second, the coefficients on the two tone measures are of larger size and statistical significance when we use the method-of-moments estimation than when we rely on OLS estimation. Our results are similar when we apply the errors-in-variables regression approach to the investment efficiency regression in equation (2).

Our results are consistent with the conjecture that the association between a company's investment and its rivals' MD\&A tone obtains because tone causes investment. Causality may, however, flow in the opposite direction and investment may cause tone. To analyze this possibility, we use a Granger causality test and estimate two regressions: Investment $_{t+1}=$ $\alpha+\beta_{1}$ Rivals $^{\prime}$ tone $_{t}+\gamma_{1}$ Investment $_{t}+\Theta$ Control variables $+\varepsilon_{t+1}$ and Rivals $^{\prime}$ tone $_{t}=$ $\alpha+\beta_{2}$ Investment $_{t-1}+\gamma_{2}$ Rivals $^{\prime}$ tone $_{t-1}+\Theta$ Control variables $+\varepsilon_{t}$, where all variables are defined as in regression (1). Granger causality is rejected in the first regression if $\beta_{1}=0$ and in the second regression if $\beta_{2}=0$. We estimate both regressions in the pooled cross-section. Our results show that, in the first regression, $\beta_{1}=0.380$ ( $t$-statistic: 6.12$)$. We cannot reject the proposition that Rivals' tone $_{t}$ Granger causes Investment $t_{t+1}$. For the second regression, we find that $\beta_{2}=0.071$ ( $t$-statistic: 1.07 ), which rejects the hypothesis that Investment $_{t-1}$ Granger causes Rivals' tone . We find similar results when we repeat the Granger causality test for investment efficiency. 


\subsection{Components of investment}

Our investment measure is an aggregate of four components: capital expenditures, $R \& D$ expenditures, acquisitions, and sales of PP\&E. To explore the role of each component, we estimate regressions (1) and (2) separately for each component. Our results from Tables 3 and 4 generally carry over to each component.

\subsection{Other}

All our regressions are estimated by first differencing our variables to account for unobservable non-varying firm characteristics. As an alternative approach, we use the level of variables and include firm fixed effects along with year fixed effects. Our results hold.

\section{Conclusion}

This study examines whether MD\&A disclosures have spillover effects for investment and investment efficiency, and whether spillover effects vary with competition fundamentals. Our results show that MD\&As have positive spillover effects for investment and investment efficiency. This evidence highlights that textual disclosures can spur not only industry investment but also the efficiency of this investment. Our study thereby extends research on spillover effects, which has not analyzed the text in disclosures. Instead, it has explored the publication of disclosures and their numerical content, and it has cautioned that the spillover effects from these disclosures can be detrimental for other companies in the industry (Durnev and Mangen, 2009; Beatty et al., 2013). Our work, in contrast, suggests that disclosures can have beneficial spillover effects.

Second, we show that competition fundamentals moderate the spillover effects of MD\&A disclosures for investment and investment efficiency. We find that the spillover effects of MD\&A disclosures for investment are stronger when firms operate in industries that have lower entry costs, are larger, and have less substitutable products, while the spillover effects of MD\&A disclosures for investment efficiency are stronger when firms operate in industries that have lower entry costs and are larger. By highlighting the role of competition in moderating spillover effects, our study extends prior research that has not analyzed this moderating role. Instead, it has explored the implications of competition for disclosures or for investment 
(Hoberg and Phillips, 2010; Li et al., 2013). Taken together, our findings extend the accounting literature by emphasizing the importance of spillover effects of textual disclosures and the role of competition in shaping these spillover effects, thereby addressing the call in Leuz and Wysocki (2016) for more research on the spillover effects of disclosures for investment. Our study also contributes to the literature in economics and finance by identifying publicly available corporate textual disclosures as a novel determinant of corporate investment. 


\section{Appendix A Definitions of Variables}

Rivals of a company are in same the 3-digit SIC industry as the company and exclude the company. Variables referring to the industry, or to rivals, are calculated as averages across all rivals (excluding the company), except if indicated otherwise. Accounting data are from COMPUSTAT and stock market data from CRSP. The letter $t$ refers to the fiscal year.

\section{Dependent variables}

- Investment: Sum of a company's capital expenditures (COMPUSTAT: CAPX), R\&D expenditures (COMPUSTAT: XRD), and acquisitions (COMPUSTAT: AQC) less cash receipts from property, plant, and equipment sales (COMPUSTAT: SPPE) multiplied by 100, all scaled by total assets (COMPUSTAT: AT).

- Investment efficiency: Minus one times the unsigned residual from a regression of a company's Investment in $t$ on the percentage change in its sales between $t-2$ and $t-1$.

\section{Explanatory variables of interest}

- Common MD\&A disclosures: Sentences in a firm's MD\&A that contain keywords referring to its industry, identified using a self-constructed algorithm.

- Competition: Competition in an industry, measured using three variables computed at the industry level: Entry costs, Industry size, and Product substitutability.

- Entry costs: Natural logarithm of weighted mean of the gross value of cost of PP\&E of each firm in the industry, the weights being each firm's industry market share.

- Firm-specific MD\&A disclosures: Sentences in a firm's MD\&A that contain keywords referring to its products or business, identified using a self-constructed algorithm.

- Industry size: Natural logarithm of total sales in an industry.

- Product substitutability: Ratio of an industry's total operating costs (the sum of cost of goods sold; selling, general, and administrative expenses; and depreciation, depletion, and amortization) to its total sales.

- Rivals' tone: Average, across all rivals of company, of the Tone of each rival's MD\&A.

- Rivals' unsigned tone: Average, across all rivals of a company, of the absolute value of the Tone of each rival's MD\&A.

- Tone: Number of positive words per 100 words in a firm's MD\&A minus number of negative words per 100 words, measured using the 2018 version of the word list from Loughran and McDonald (2011). 
- Unsigned tone: Absolute value of the Tone of a firm's MD\&A.

\section{Control variables}

- Abnormal returns at rivals' earnings announcements: Absolute value of a firm's market-adjusted returns (the market is the value-weighted CRSP index) cumulated during the $[-1,+1]$ window around each quarterly earnings announcement date of its rival in the year before the release of the $t-110 \mathrm{~K}$ that contains the MD\&A, averaged across all rivals and quarterly earnings announcement dates in $t-2$.

- Analyst earnings forecast: Average of the forecast for a firm's year $t$ earnings per share (from $\mathrm{I} / \mathrm{B} / \mathrm{E} / \mathrm{S})$ across all four quarters of $t-1$ and analysts, scale by total assets in $t-2$.

- Cash: Net income plus depreciation and amortization, all scaled by prior-year total assets.

- Financial constraints: Linear combination of $t-1$ cash flows, dividends, cash balances, and leverage, computed as -1.108Cash - 42.900Dividends - 1.007Cash balances +3.812 Leverage, where Cash is defined as above, Dividends is the sum of common and preferred dividends scaled by total assets, Cash balances is cash and short-term investments, and Leverage is long-term debt and debt in current liabilities scaled by the sum of long-term debt, debt in current liabilities, and shareholders' equity.

- Sales growth: Sales in $t-1$ minus sales in $t-2$, all scaled by $t-2$ sales.

- Stock price informativeness: Computed via principal component analysis as - [0.21 Illiquidity +0.33 Return autocorrelation +0.84 Firm-specific return variation] (Bharath et al., 2009). Illiquidity is $\sqrt{\frac{1}{\text { days }} \sum_{d=1}^{\text {days }} \frac{|R|}{V}}$, with $R$ the return volume of a firm's shares in $t-1, V$ the dollar volume, and days the number of trading days. Return autocorrelation, $A C$, is obtained from estimating $r=$ $A+B r+A C r V+\varepsilon$, where $r$ is the return on day $d$ in $t-1 ; V$ daily volume; and $A, A C$, and $B$ regression coefficients. Firm-specific return variation is $\ln \left[\frac{R^{2}}{1-R^{2}}\right]$, where $R^{2}$ is from $r=A+B r^{i n d}+C r^{m}+\varepsilon$, estimated for each firm and $t-1$ using daily return data, with $r^{i n d}$ the two-digit SIC value-weighted return and $r^{m}$ the CRSP value-weighted market index. Our results hold if we use illiquidity, returns autocorrelation, and firm-specific return variation separately.

- Stock returns: Buy-and-hold returns during the 12 months before the end of $t$.

- Tobin's Q: For each company, total assets plus the market value of equity minus the book value of equity, all scaled by total assets. For rivals, the sum across all rivals of their individual market value (total assets plus the market value of equity minus the book value of equity) divided by the sum across all rivals of their total assets.

- Total assets: Natural logarithm of total assets. 


\section{References}

Aghion, P., Bloom, N., Blundell, R., Griffith, R., Howitt, P., 2005. Competition and innovation: An inverted-U relationship. Q. J. Econ. 120, 701-728.

Almeida, P., Kogut, B., 1999. Localization of knowledge and the mobility of engineers in regional networks. Manag. Sci. 45, 905-917.

Arena, M., Julio, B., 2015. The effects of securities class action litigation on corporate liquidity and investment policy. J. Financ. Quant. Anal. 50, 251-275.

Aslan, H., Kumar, P., 2016. The product market effects of hedge fund activism. J. Financ. Econ. $119,226-248$.

Badertscher, B., Shroff, N., White, H.D., 2013. Externalities of public firm presence: Evidence from private firms' investment decisions. J. Financ. Econ. 109, 682-706.

Ball, C., Hoberg, G., Maksimovic, V., 2015. Disclosure, Business Change and Earnings Quality. SSRN Working Paper 2260371.

Barro, R.J., 1990. The stock market and investment. Rev. Financ. Stud. 3, 115-131.

Beatty, A., Liao, S., Yu, J.J., 2013. The spillover effect of fraudulent financial reporting on peer firms' investments. J. Account. Econ. 55, 183-205.

Bernard, D., 2016. Is the risk of product market predation a cost of disclosure? J. Account. Econ. $62,305-325$.

Bharath, S.T., Pasquariello, P., Wu, G., 2009. Does asymmetric information drive capital structure decisions? Rev. Financ. Stud. 22, 3211-3243.

Biddle, G.C., Hillary, G., Verdi, R.S., 2009. How does financial reporting quality relate to investment efficiency? J. Account. Econ. 48, 112-131.

Bolton, P., Chen, H., Wang, N., 2013. Market timing, investment, and risk management. J. Financ. Econ. 109, 40-62.

Bresnahan, T.F., Reiss, P.C., 1987. Do entry conditions vary across markets? Brookings Pap. Econ. Act. 1987, 833-881.

Brown, S., Tucker, J.W., 2011. Large sample evidence on firms' year-over-year MD\&A modifications. J. Account. Res. 49, 309-346.

Bryan, S.H., 1997. Incremental information content of required disclosures contained in management discussion and analysis. Account. Rev. 72, 285-301.

Caves, R.E., 1971. International corporations: The industrial economics of foreign investment. Economica 38, 1-27.

Cellini, R., Lambertini, L., 2002. A differential game approach to investment in product differentiation. J. Econ. Dyn. Control 27, 51-62.

Chen, M.J., 1996. Competitor analysis and interfirm rivalry: Toward a theoretical integration. Acad. Manag. Rev. 21, 100-134.

Chen, Q., Goldstein, I., Jiang, W., 2007. Price informativeness and investment sensitivity to stock prices. Rev. Financ. Stud. 20, 619-650. 
Chen, W., Hribar, P., Melessa, S., 2018. Incorrect inferences when using residuals as dependent variables. J. Account. Res. 56, 751-796.

Clinch, G., Verrecchia, R.E., 1997. Competitive disadvantage and discretionary disclosure in industries. Aust. J. Manag. 22, 125-137.

Cole, C.J., Jones, C.L., 2005. Management discussion and analysis: A review and implications for future research. J. Account. Lit. 24, 135-174.

Corona, C., Nan, L., 2013. Preannouncing competitive decisions in oligopoly markets. J. Account. Econ. 56, 73-90.

Cuñat, V., Guadalupe, M., 2009. Globalization and the provision of incentives inside the firm: The effect of foreign competition. J. Lab. Econ. 27, 179-212.

Darrough, M.N., 1993. Disclosure policy and competition: Cournot vs. Bertrand. Account. Rev. $68,534-561$.

Darrough, M.N., Stoughton, N.M., 1990. Financial disclosure policy in an entry game. J. Account. Econ. 12, 219-243.

Davis, A.K., Tama-Sweet, I., 2012. Managers' use of language across alternative disclosure outlets: Earnings press releases versus MD\&A. Contemp. Account. Res. 29, 804-837.

De Bondt, R., 1996. Spillovers and innovative activities. Intern. J. Ind. Organ. 15, 1-28.

De Bondt, R., Slaets, P., Cassiman, B., 1992. The degree of spillovers and the number of rivals for maximum effective R\&D. Intern. J. Ind. Organ. 10, 35-54.

Denis, D.J., Sibilkov, V., 2010. Financial constraints, investment, and the value of cash holdings. Rev. Financ. Stud. 23, 247-269.

Dougal, C., Parsons, C.A., Titman, S., 2015. Urban vibrancy and corporate growth. J. Financ. 70, $163-210$.

Durnev, A., Mangen, C., 2009. Corporate investments: Learning from restatements. J. Account. Res. 47, 679-720.

[dataset] Durnev, A., Mangen, C., 2019. Durnev and Mangen data. http://www.concordia.ca/ content/dam/jmsb/docs/research/researchdata/2019-durnev-mangen-data.xlsx.

Durnev, A., Morck, R., Yeung, B., 2004. Value-enhancing capital budgeting and firm-specific stock return variation. J. Financ. 59, 65-105.

Dyer, T., Lang, M., Stice-Lawrence, L., 2016. Do managers really guide through the fog? On the challenges in assessing the causes of voluntary disclosure. J. Account. Econ. 62, 270-276.

Dyer, T., Lang, M., Stice-Lawrence, L., 2017. The evolution of 10-K textual disclosure: Evidence from Latent Dirichlet Allocation. J. Account. Econ. 64, 221-245.

Ellis, J.A., Fee, C.E., Thomas, S.E., 2012. Proprietary costs and the disclosure of information about customers. J. Account. Res. 50, 685-727.

Erickson, T., Whited, T.M., 2000. Measurement error and the relationship between investment and q. J. Polit. Econ. 108, 1027-1057.

Erickson, T., Whited, T.M., 2002. Two-step GMM estimation of the errors-in-variables model using higher-order moments. Econ. Theory 18, 776-799. 
Feenstra, R.C., Weinstein, D.E., 2017. Globalization, markups, and US welfare. J. Polit. Econ. 125, 1040-1074.

Ferreira, M., Laux, P., 2007. Corporate governance, idiosyncratic risk and information flow. J. Financ. 62, 951-989.

Foucault, T., Fresard, L., 2014. Learning from peers' stock prices and corporate investment. J. Financ. Econ. 111, 554-577.

Francis, J.R., Martin, X., 2010. Acquisition profitability and timely loss recognition. J. Account. Econ. 49, 161-178.

Frankel, R., Jennings, J., Lee, J., 2016. Using unstructured and qualitative disclosures to explain accruals. J. Account. Econ. 62, 209-227.

Frésard, L., Valta, P., 2016. How does corporate investment respond to increased entry threat? Rev. Corp. Financ. Stud. 5, 1-35.

Giroud, X., Mueller, H.M., 2011. Corporate governance, product market competition, and equity prices. J. Financ. 66, 563-600.

Glaser, M., Lopez-de-Silanes, F., Sautner, Z., 2013. Opening the black box: Internal capital markets and managerial power. J. Financ. 68, 1577-1631.

Gompers, P.A., Ishii, J.L., Metrick, A., 2003. Corporate governance and equity prices. Q. J. Econ. $118,107-155$.

Guo, R.J., Lev, B., Zhou, N., 2004. Competitive costs of disclosure by biotech IPOs. J. Account. Res. 42, 319-355.

Gutiérrez, G., Philippon, T., 2017. Declining competition and investment in the U.S. NBER Working Paper 23583.

Hart, O.D., 1983. The market mechanism as an incentive scheme. Bell J. Econ. 14, 366-382.

Hennessy, C.A., Whited, T.M., 2007. How costly is external financing? Evidence from a structural estimation. J. Financ. 62, 1705-1745.

Hoberg, G., 2016. Discussion of using unstructured and qualitative disclosures to explain accruals. J. Account. Econ. 62, 228-233.

Hoberg, G., Phillips, G., 2010. Product market synergies and competition in mergers and acquisitions: A text-based analysis. Rev. Financ. Stud. 23, 3773-3811.

Hoberg, G., Phillips, G.M., 2016. Text-based network industries and endogenous product differentiation. J. Polit. Econ. 124, 1423-1465.

Hutton, A.P., Miller, G.S., Skinner, D.J., 2003. The role of supplementary statements with management earnings forecasts. J. Account. Res. 41, 867-890.

Jin, G.Z., 2005. Competition and disclosure incentives: An empirical study of HMOs. Rand J. Econ. 3, 93-112.

Karuna, C., 2007. Industry product market competition and managerial incentives. J. Account. Econ. 43, 275-297.

Kuhnen, C.M., 2015. Asymmetric learning from financial information. J. Financ. 70, 2029-2062. 
Lang, M.H., Lundholm, R.L., 2000. Voluntary disclosure and equity offerings: Reducing information asymmetry or hyping the stock? Contemp. Account. Res. 17, 623-662.

Leuz, C., Wysocki, P.D., 2016. The economics of disclosure and financial reporting regulation: Evidence and suggestions for future research. J. Account. Res. 54, 525-622.

Li, F., 2010a. The information content of forward-looking statements in corporate filings - A naive Bayesian machine learning approach. J. Account. Res. 48, 1049-1201.

Li, F., Lundholm, R.L., Minnis, M., 2013. A measure of competition based on 10-K filings. J. Account. Res. 51, 399-436.

Li, X., 2010b. The impacts of product market competition on the quantity and quality of voluntary disclosures. Rev. Account. Stud. 15, 663-711.

Li, Y., Lin, Y., Zhang, L., 2018. Trade secrets law and corporate disclosure: Causal evidence on the proprietary cost hypothesis. J. Account. Res. 56, 265-308.

Loughran, T., McDonald, B., 2011. When is a liability not a liability? Textual analysis, dictionaries, and 10-Ks. J. Financ. 66, 35-65.

Loughran, T., McDonald, B., 2015. The use of word lists in textual analysis. J. Behav. Financ. 16, $1-11$.

Loughran, T., McDonald, B., 2016. Textual analysis in Accounting and Finance: A survey. J. Account. Res. 54, 1187-1230.

[dataset] Loughran, T., McDonald, B., 2018. Loughran and McDonald sentiment wordlist. https: //sraf.nd.edu.

MacKay, P., Phillips, G.M., 2005. How does industry affect firm financial structure? Rev. Financ. Stud. 18, 1433-1466.

Malmendier, U., Tate, G., 2005. CEO overconfidence and corporate investment. J. Financ. 60, 2661-2700.

Marin, J., Poulter, A., 2004. Dissemination of competitive intelligence. J. Inf. Sci. 30, 165-180.

Mercer, M., 2004. How do investors assess the credibility of management disclosures? Account. Horiz. 18, 185-196.

Mowery, D.C., Oxley, J.E., Silverman, B.S., 1996. Strategic alliances and interfirm knowledge transfer. Strateg. Manag. J. 17, 77-91.

Pan, Y., Wang, T.Y., Weisbach, M.S., 2016. CEO Investment Cycles. Rev. Financ. Stud. 29, $2955-2999$.

Peters, R.H., Taylor, L.A., 2017. Intangible capital and the investment- $q$ relation. J. Financ. Econ. $123,251-272$.

Raith, M., 1996. A general model of information sharing in oligopoly. J. Econ. Theory 71, 260-288.

Raith, M., 2003. Competition, risk and managerial incentives. Am. Econ. Rev. 93, 1425-1436.

Roychowdhury, S., Shroff, N., Verdi, R.S., 2019. The effects of financial reporting and disclosure on corporate investment: A review. J. Account. Econ. (forthcoming).

Sadka, G., 2006. The economic consequences of accounting fraud in product markets: Theory and a case from a U.S. telecommunications industry (WorldCom). Am. Law Econ. Rev. 8, 439-475. 
Scharfstein, D., 1988. Product-market competition and managerial slack. Rand J. Econ. 19, 147-155.

Scharfstein, D.S., Stein, J.C., 2000. The dark side of internal capital markets: Divisional rent-seeking and inefficient investment. J. Financ. 55, 2537-2564.

Schmidt, K.M., 1997. Managerial incentives and product market competition. Rev. Econ. Stud. 64, $191-213$.

Shroff, N., Verdi, R.S., Yost, B.P., 2017. When does the peer information environment matter? J. Account. Econ. 64, 183-214.

Stivers, A., 2004. Unraveling of information: Competition and uncertainty. Top. Theor. Econ. 4, $1-16$.

Tetlock, P.C., 2007. Giving content to investor sentiment: The role of the media in the stock market. J. Financ. 62, 1139-1168.

Tetlock, P.C., Saar-Tsechansky, M., Macskassy, S., 2008. More than words: Quantifying language to measure firms' fundamentals. J. Financ. 63, 1437-1467.

Tobin, J., 1969. A general equilibrium approach to monetary theory. J. Money Credit Bank. 1, $15-29$.

Wagenhofer, A., 1990. Voluntary disclosure with a strategic opponent. J. Account. Econ. 12, $341-363$.

Zahra, S.A., George, G., 2002. Absorptive capacity: A review, reconceptualization, and extension. Acad. Manag. Rev. 27, 185-203.

Zhu, K., Weyant, J.P., 2003. Strategic decisions of new technology adoption under asymmetric information: A game-theoretic model. Decis. Sci. J. 34, 643-675. 
Table 1

Sample, 1996-2016

This table shows sample selection details. Numbers in parentheses are observations that are dropped.

\begin{tabular}{lcc}
\hline & Firms & Firm-years \\
\hline COMPUSTAT/CRSP firms with data on major variables, 1996-2016 & 20,897 & 142,843 \\
Fiscal year changes & $(3,715)$ & $(14,107)$ \\
\cline { 2 - 3 } & 17,182 & 128,736 \\
Utilities and financials & $(3,018)$ & $(20,182)$ \\
\cline { 2 - 3 } & 14,164 & 108,554 \\
Missing or unreadable MD\&As & $(5,294)$ & $(48,177)$ \\
Final sample & 8,870 & 60,377 \\
\hline
\end{tabular}




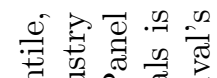

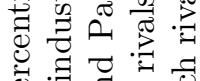
范 矛岤《6

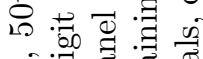
0

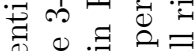

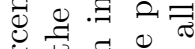

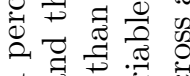
구

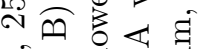

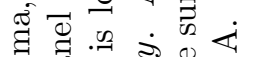
当

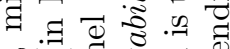
की तै त्ञ

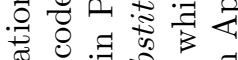
. ज 包记

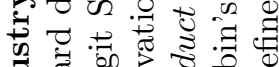

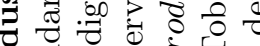
. दै की $\Rightarrow$ 药 $\Rightarrow \begin{aligned} & 0 \\ & 0\end{aligned}$

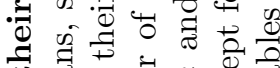

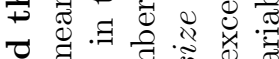
उ द्व है के ส ต की స . ᄅ sol 00000

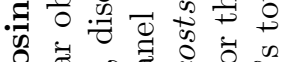

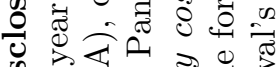
늘

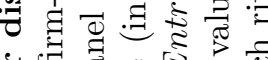

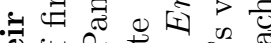

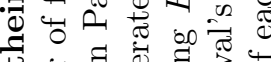

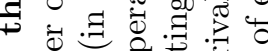
की

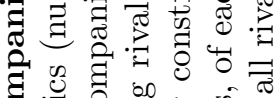
0. on $\Xi$ क क. .

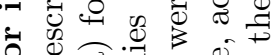

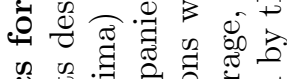

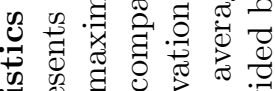
苛 0 b की 0.7 .

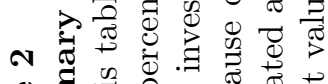

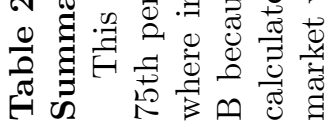

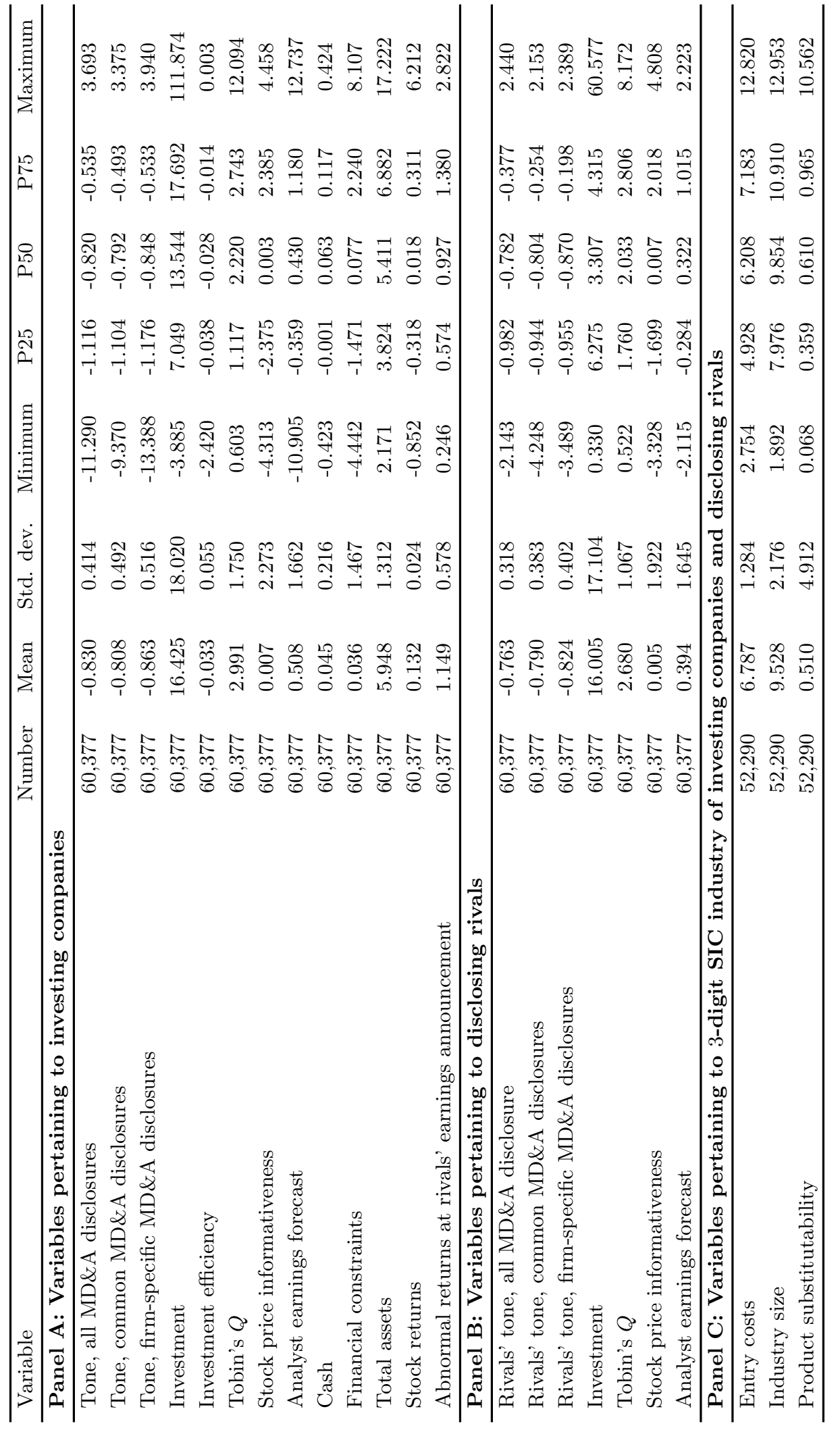


Table 3

The association between the change in a company's investment and the change in rivals' MD\&A tone

This table reports the results from estimating OLS regressions between 1996 and 2016 in the pooled cross-section with year fixed effects. The dependent variable is Change in investment, the change between $t+1$ and $t$ in the sum of a company's capital expenditures, $R \& D$ expenditures, and acquisitions, minus its cash receipts from the sales of property, plant, and equipment (multiplied by 100), all scaled by lagged total assets. The explanatory variable of interest is Change in rivals ${ }^{\prime}$ tone, the change between $t$ and $t-1$ in the average, across all rivals, of each rival's MD\&A tone. Rivals are all firms in the same 3-digit SIC code as the company, excluding the latter. Tone is the number of positive words per 100 words in a firm's MD\&A minus the number of negative words per 100 words, measured using the 2018 version of the word list from Loughran and McDonald (2011). Entry costs, Industry size and Product substitutability are calculated for the investing company's 3-digit SIC code in $t$ (excluding the company). Variables are specified in Appendix A $t$-statistics (reported in parentheses) are based on standard errors clustered by 3 -digit SIC code and are robust to heteroscedasticity. $* * *, * *, *$ indicate significance levels for two-tailed tests at the $1 \%$, $5 \%$, and $10 \%$ level, respectively.

\begin{tabular}{|c|c|c|c|c|}
\hline Model & 1 & 2 & 3 & 4 \\
\hline Change in rivals' tone & & $\begin{array}{c}0.258^{* * *} \\
(5.86)\end{array}$ & $\begin{array}{c}0.148^{* * *} \\
(5.20)\end{array}$ & $\begin{array}{c}0.136^{* * *} \\
(4.52)\end{array}$ \\
\hline Entry costs $\times$ Change in rivals' tone & & & & $\begin{array}{c}-0.192^{* * *} \\
(-4.28)\end{array}$ \\
\hline Industry size $\times$ Change in rivals' tone & & & & $\begin{array}{c}1.882^{* * *} \\
(6.12)\end{array}$ \\
\hline Product substitutability $\times$ Change in rivals' tone & & & & $\begin{array}{c}-0.082^{* *} \\
(-2.45)\end{array}$ \\
\hline Entry costs & & & & $\begin{array}{c}-0.076^{*} \\
(-1.82)\end{array}$ \\
\hline Industry size & & & & $\begin{array}{c}-0.067 * * * \\
(-4.20)\end{array}$ \\
\hline Product substitutability & & & & $\begin{array}{l}-0.170 \\
(-1.46)\end{array}$ \\
\hline Change in rivals' investment & $\begin{array}{c}0.377^{* * *} \\
(18.26)\end{array}$ & & $\begin{array}{c}0.256^{* * *} \\
(15.45)\end{array}$ & $\begin{array}{c}0.261^{* * *} \\
(15.18)\end{array}$ \\
\hline Change in rivals' Tobin's $Q$ & $\begin{array}{c}0.469^{* *} \\
(1.96)\end{array}$ & $\begin{array}{c}0.417^{* *} \\
(2.05)\end{array}$ & $\begin{array}{l}0.439 \\
(1.61)\end{array}$ & $\begin{array}{l}0.400^{*} \\
(1.91)\end{array}$ \\
\hline Change in rivals' stock price informativeness & $\begin{array}{l}0.078^{*} \\
(1.81)\end{array}$ & $\begin{array}{l}0.114 \\
(1.64)\end{array}$ & $\begin{array}{l}0.088 \\
(1.49)\end{array}$ & $\begin{array}{l}0.194 \\
(1.52)\end{array}$ \\
\hline Change in rivals' analyst earnings forecast & $\begin{array}{c}0.023^{* * *} \\
(3.23)\end{array}$ & $\begin{array}{c}0.027^{* * *} \\
(3.31)\end{array}$ & $\begin{array}{c}0.033^{* * *} \\
(3.34) \\
\end{array}$ & $\begin{array}{c}0.039^{* * *} \\
(3.31) \\
\end{array}$ \\
\hline Change in tone & $\begin{array}{c}0.216^{* * *} \\
(4.25)\end{array}$ & $\begin{array}{c}0.192^{* *} \\
(2.24)\end{array}$ & $\begin{array}{l}0.108^{*} \\
(1.94)\end{array}$ & $\begin{array}{c}0.144^{* * *} \\
(4.16)\end{array}$ \\
\hline Change in Tobin's $Q$ & $\begin{array}{c}0.529^{* * *} \\
(4.44)\end{array}$ & $\begin{array}{c}0.400^{* * *} \\
(3.29)\end{array}$ & $\begin{array}{c}0.350^{* * *} \\
(3.58)\end{array}$ & $\begin{array}{c}0.380^{* *} \\
(2.52)\end{array}$ \\
\hline Change in stock price informativeness & $\begin{array}{l}0.215 \\
(0.66)\end{array}$ & $\begin{array}{l}0.263 \\
(1.61)\end{array}$ & $\begin{array}{l}0.188 \\
(1.43)\end{array}$ & $\begin{array}{l}0.231 \\
(1.39)\end{array}$ \\
\hline Change in analyst earnings forecast & $\begin{array}{c}0.020^{* *} \\
(2.24)\end{array}$ & $\begin{array}{c}0.012^{* *} \\
(2.34)\end{array}$ & $\begin{array}{c}0.013^{* *} \\
(2.28)\end{array}$ & $\begin{array}{c}0.033^{* *} \\
(2.39)\end{array}$ \\
\hline Change in stock returns & $\begin{array}{c}-0.019 * * * \\
(-3.55)\end{array}$ & $\begin{array}{c}-0.011^{* * *} \\
(-3.89)\end{array}$ & $\begin{array}{c}-0.015^{* * *} \\
(-3.88)\end{array}$ & $\begin{array}{c}-0.011 * * * \\
(-4.11)\end{array}$ \\
\hline $\begin{array}{l}\text { Change in abnormal returns } \\
\text { at rivals' earnings announcements }\end{array}$ & $\begin{array}{l}0.015 \\
(0.47)\end{array}$ & $\begin{array}{l}0.027 \\
(0.67)\end{array}$ & $\begin{array}{l}0.035 \\
(0.64)\end{array}$ & $\begin{array}{l}0.040 \\
(0.51)\end{array}$ \\
\hline Change in company's cash & $\begin{array}{c}1.813^{* * *} \\
(4.44)\end{array}$ & $\begin{array}{c}2.314^{* * *} \\
(6.15)\end{array}$ & $\begin{array}{c}2.085^{* * *} \\
(5.28)\end{array}$ & $\begin{array}{c}2.189^{* * *} \\
(5.34)\end{array}$ \\
\hline Change in financial constraints & $\begin{array}{c}-0.006^{* * *} \\
(-2.91)\end{array}$ & $\begin{array}{c}-0.112^{* * *} \\
(-3.10)\end{array}$ & $\begin{array}{c}-0.114^{* * *} \\
(-3.02)\end{array}$ & $\begin{array}{c}-0.078^{* * *} \\
(-3.04)\end{array}$ \\
\hline Change in total assets & $\begin{array}{c}-0.499^{* * *} \\
(-10.99)\end{array}$ & $\begin{array}{c}-0.521^{* * *} \\
(-9.96)\end{array}$ & $\begin{array}{c}-0.440 * * * \\
(-9.89)\end{array}$ & $\begin{array}{c}-0.473^{* * *} \\
(-9.77)\end{array}$ \\
\hline Year fixed effects & significant & significant & significant & significant \\
\hline Adj. $R^{2}$ & $28.5 \%$ & $31.4 \%$ & $29.8 \%$ & $34.0 \%$ \\
\hline No. obs. & 52,290 & 52,290 & 52,290 & 52,290 \\
\hline
\end{tabular}


Table 4

The association between the change in a company's investment efficiency and the change in rivals' unsigned MD\&A tone

This table reports the results from estimating OLS regressions between 1996 and 2016 in the pooled cross-section with year fixed effects. The dependent variable is Change in investment efficiency, the change between $t+1$ and $t$ in a company's investment efficiency. Investment efficiency in $t$ is minus one times the absolute value of the residual from a regression, estimated in the pooled cross-section, of the company's investment in $t$ on the percentage change in its sales between $t-2$ and $t-1$. The explanatory variable of interest is Change in rivals' unsigned tone, the change between $t$ and $t-1$ in the average, across all rivals, of the absolute value of each rival's MD\&A tone. Rivals are all firms in the same 3-digit SIC code as the investing company, excluding the latter. Tone is the number of positive words per 100 words in a firm's MD\&A minus the number of negative words per 100 words, measured using the 2018 version of the word list from Loughran and McDonald (2011). Entry costs, Industry size and Product substitutability are calculated for the investing company's 3-digit SIC code in $t$ (excluding the company). Variables are specified in Appendix A $t$-statistics (reported in parentheses) are based on standard errors clustered by 3 -digit SIC code and are robust to heteroscedasticity. $* * *, * *, *$ indicate significance levels for two-tailed tests at the $1 \%$, $5 \%$, and $10 \%$ level, respectively.

\begin{tabular}{|c|c|c|c|c|}
\hline Model & 1 & 2 & 3 & 4 \\
\hline Change in rivals' unsigned tone & & $\begin{array}{c}0.208^{* * *} \\
(6.12)\end{array}$ & $\begin{array}{c}0.084^{* * *} \\
(3.18)\end{array}$ & $\begin{array}{c}0.194^{* * *} \\
(5.21)\end{array}$ \\
\hline Entry costs $\times$ Change in rivals' unsigned tone & & & & $\begin{array}{c}-0.026^{* * *} \\
(-3.48)\end{array}$ \\
\hline Industry size $\times$ Change in rivals' unsigned tone & & & & $\begin{array}{c}7.812^{* * *} \\
(6.21)\end{array}$ \\
\hline Product substitutability $\times$ Change in rivals' unsigned tone & & & & $\begin{array}{l}-0.014 \\
(-0.38)\end{array}$ \\
\hline Entry costs & & & & $\begin{array}{c}-0.012^{* * *} \\
(-2.76)\end{array}$ \\
\hline Industry size & & & & $\begin{array}{l}-0.006 \\
(-0.48)\end{array}$ \\
\hline Product substitutability & & & & $\begin{array}{l}-0.092 \\
(-1.14)\end{array}$ \\
\hline Change in rivals' investment & $\begin{array}{c}0.062^{* *} \\
(1.98)\end{array}$ & & $\begin{array}{l}0.035 \\
(1.05)\end{array}$ & $\begin{array}{l}0.050 \\
(1.50)\end{array}$ \\
\hline Change in rivals' Tobin's $Q$ & $\begin{array}{l}0.209^{*} \\
(1.85)\end{array}$ & $\begin{array}{l}0.236 \\
(1.38)\end{array}$ & $\begin{array}{c}0.248^{* *} \\
(2.03)\end{array}$ & $\begin{array}{l}0.218 \\
(1.64)\end{array}$ \\
\hline Change in rivals' stock price informativeness & $\begin{array}{l}0.195^{*} \\
(1.77)\end{array}$ & $\begin{array}{l}0.139 \\
(1.64)\end{array}$ & $\begin{array}{l}0.181^{*} \\
(1.67)\end{array}$ & $\begin{array}{l}0.146 \\
(1.29)\end{array}$ \\
\hline Change in rivals' analyst earnings forecast & $\begin{array}{c}0.021^{* * *} \\
(3.96) \\
\end{array}$ & $\begin{array}{c}0.013^{* * *} \\
(3.13)\end{array}$ & $\begin{array}{c}0.019^{* * *} \\
(3.42) \\
\end{array}$ & $\begin{array}{c}0.014^{* * *} \\
(3.97) \\
\end{array}$ \\
\hline Change in unsigned tone & $\begin{array}{c}3.237^{* * *} \\
(4.29)\end{array}$ & $\begin{array}{c}3.170^{* * *} \\
(3.08)\end{array}$ & $\begin{array}{c}2.560 * * \\
(2.26)\end{array}$ & $\begin{array}{c}2.390^{* * *} \\
(3.29)\end{array}$ \\
\hline Change in Tobin's $Q$ & $\begin{array}{c}0.111^{* *} \\
(2.11)\end{array}$ & $\begin{array}{c}0.172^{* * *} \\
(3.68)\end{array}$ & $\begin{array}{c}0.112^{* * *} \\
(3.93)\end{array}$ & $\begin{array}{c}0.137^{* * *} \\
(3.20)\end{array}$ \\
\hline Change in stock price informativeness & $\begin{array}{l}-0.013 \\
(-0.98)\end{array}$ & $\begin{array}{l}0.092 \\
(1.20)\end{array}$ & $\begin{array}{c}-0.045^{*} \\
(-1.70)\end{array}$ & $\begin{array}{l}0.032 \\
(0.87)\end{array}$ \\
\hline Change in analyst earnings forecast & $\begin{array}{c}0.086^{* *} \\
(2.10)\end{array}$ & $\begin{array}{c}0.132^{* *} \\
(2.09)\end{array}$ & $\begin{array}{c}0.057^{* *} \\
(2.26)\end{array}$ & $\begin{array}{c}0.122^{* *} \\
(2.22)\end{array}$ \\
\hline Change in stock returns & $\begin{array}{c}-0.020^{* * *} \\
(-4.72)\end{array}$ & $\begin{array}{c}-0.016^{* * *} \\
(-3.67)\end{array}$ & $\begin{array}{c}-0.019^{* * *} \\
(-4.59)\end{array}$ & $\begin{array}{c}-0.012^{* * *} \\
(-4.42)\end{array}$ \\
\hline $\begin{array}{l}\text { Change in abnormal returns } \\
\text { at rivals' earnings announcements }\end{array}$ & $\begin{array}{l}0.019 \\
(0.71)\end{array}$ & $\begin{array}{l}0.011 \\
(0.59)\end{array}$ & $\begin{array}{l}0.016 \\
(0.82)\end{array}$ & $\begin{array}{l}-0.012 \\
(-0.21)\end{array}$ \\
\hline Change in cash & $\begin{array}{c}2.163^{* * *} \\
(4.17)\end{array}$ & $\begin{array}{c}2.584^{* * *} \\
(3.88)\end{array}$ & $\begin{array}{c}2.399 * * * \\
(3.20)\end{array}$ & $\begin{array}{c}2.549^{* * *} \\
(4.32)\end{array}$ \\
\hline Change in financial constraints & $\begin{array}{c}-0.215^{* * *} \\
(-2.85)\end{array}$ & $\begin{array}{c}-0.362^{* * *} \\
(-2.81)\end{array}$ & $\begin{array}{c}-0.375^{* *} \\
(-2.47)\end{array}$ & $\begin{array}{c}-0.330^{* *} \\
(-2.06)\end{array}$ \\
\hline Change in total assets & $\begin{array}{c}-0.015^{* *} \\
(-2.40)\end{array}$ & $\begin{array}{l}-0.084 \\
(-1.24)\end{array}$ & $\begin{array}{c}-0.111^{* *} \\
(-2.45)\end{array}$ & $\begin{array}{c}-0.064^{*} \\
(-1.88)\end{array}$ \\
\hline Year fixed effects & significant & significant & significant & significant \\
\hline Adj. $R^{2}$ & $28.1 \%$ & $27.3 \%$ & $30.2 \%$ & $27.7 \%$ \\
\hline No. obs. & 52,290 & 52,290 & 52,290 & 52,290 \\
\hline
\end{tabular}






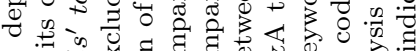

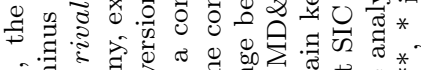

य范

ఫ

记潒

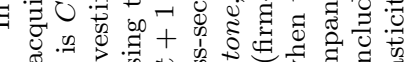

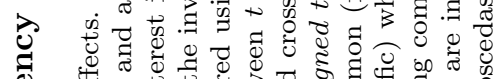

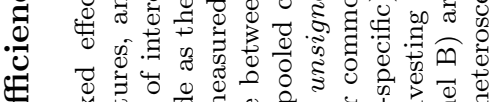

$凶$ :

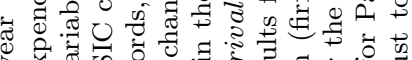

X

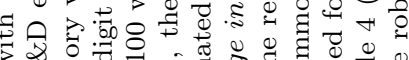

की

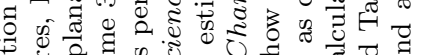



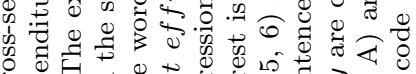

U.

ब

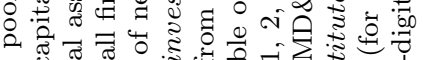

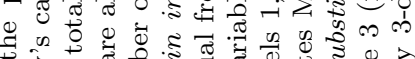

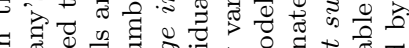



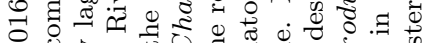

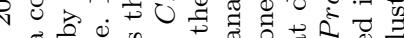

च

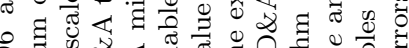

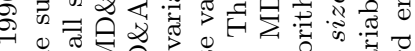

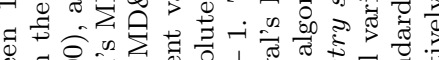

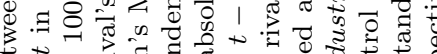

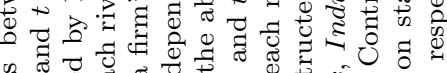

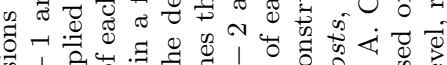

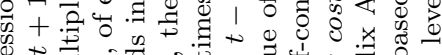

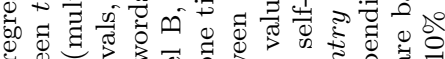

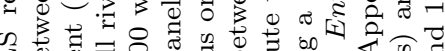

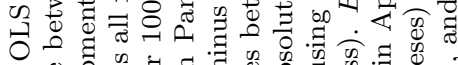

so

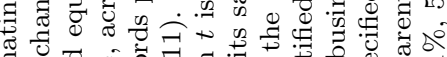

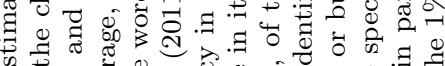

के

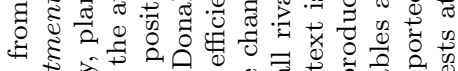

क के

क人

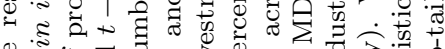

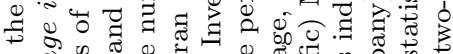

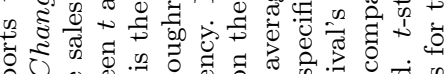

家记

.

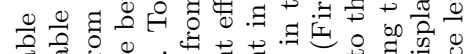

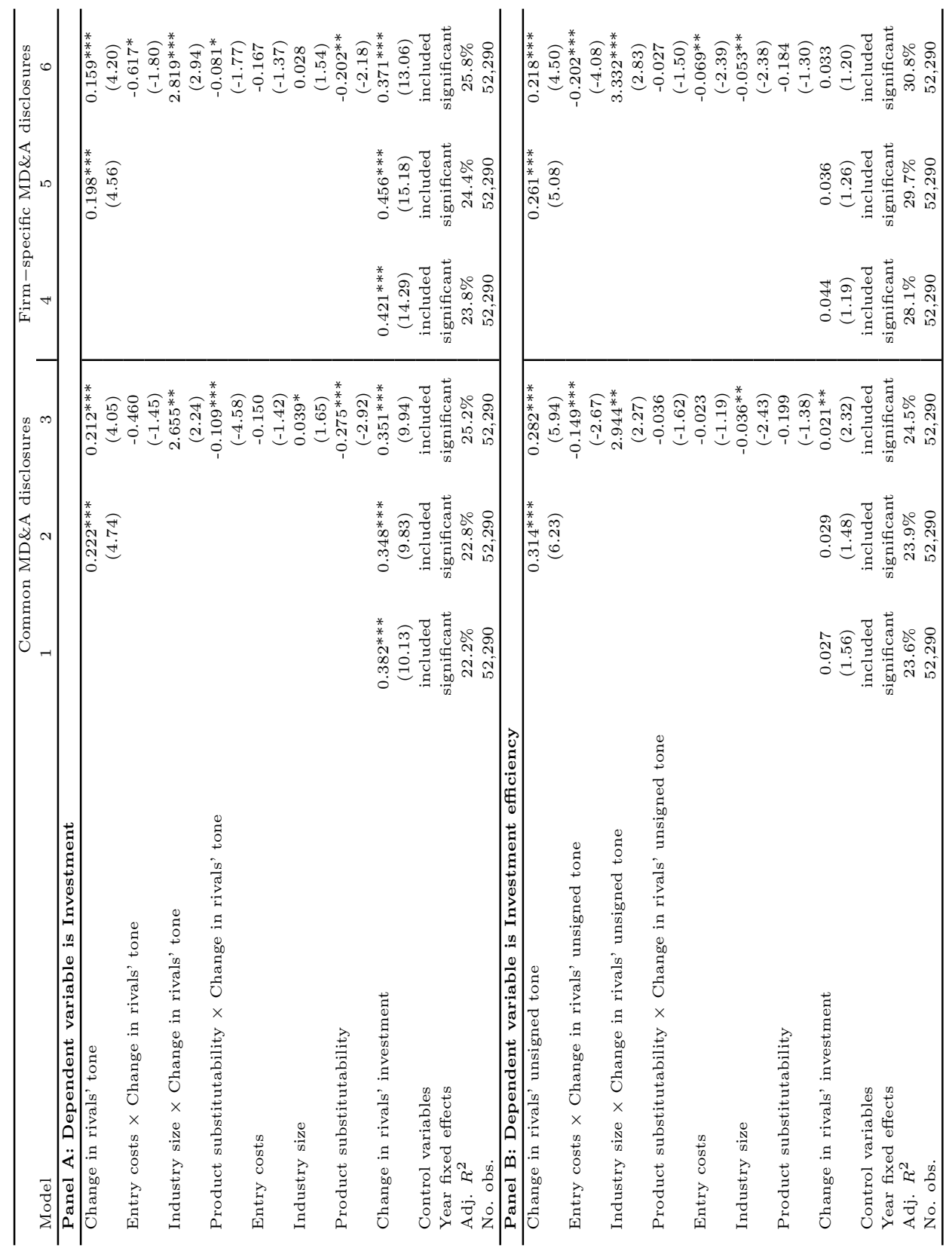

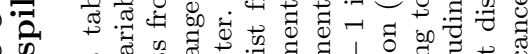

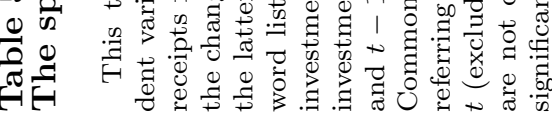

